Royal Netherlands Institute for Sea Research

This is a postprint of:

Buckles, L.K., Weijers, J.W.H., Verschuren, D. \& Sinninghe Damsté, J.S., (2014). Sources of core and intact branched tetraether membrane lipids in the lacustrine environment: Anatomy of Lake Challa and its catchment, equatorial East Africa. Geochimica et Cosmochimica Acta, 140, 106-126

Published version: $\underline{\text { dx.doi.org/10.1016/i.gca.2014.04.042 }}$

Link NIOZ Repository: $\underline{w w w . v l i z . b e / n l / i m i s ? m o d u l e=r e f \& r e f i d=241513 ~}$

[Article begins on next page]

The NIOZ Repository gives free access to the digital collection of the work of the Royal Netherlands Institute for Sea Research. This archive is managed according to the principles of the Open Access Movement, and the Open Archive Initiative. Each publication should be cited to its original source - please use the reference as presented.

When using parts of, or whole publications in your own work, permission from the author(s) or copyright holder(s) is always needed. 
Buckles et al., Geochim. Cosmochim. Acta 140, 106-126 (2014)

\title{
SOURCES OF CORE AND INTACT BRANCHED TETRAETHER MEMBRANE LIPIDS IN THE LACUSTRINE ENVIRONMENT: ANATOMY OF LAKE CHALLA AND ITS CATCHMENT, EQUATORIAL EAST AFRICA
}

\author{
Laura K. Buckles $^{\text {a }}$, Johan W. H. Weijers ${ }^{\mathrm{a}, *}$, Dirk Verschuren ${ }^{\mathrm{b}}$ \\ and Jaap S. Sinninghe Damstét ${ }^{\mathrm{a}, \mathrm{c}, \dagger}$
}

\begin{abstract}
${ }^{a}$ University of Utrecht, Faculty of Geosciences, P.O. Box 80.021, 3508 TA Utrecht, The Netherlands

${ }^{\mathrm{b}}$ Limnology Unit, Department of Biology, Ghent University, K. L. Ledeganckstraat 35, B-9000 Gent, Belgium

${ }^{\mathrm{c}}$ NIOZ Royal Netherlands Institute for Sea Research, Department of Marine Organic Biogeochemistry, P.O. Box 59, 1790 AB Den Burg, Texel, The Netherlands

* Present address: Shell Global Solutions International B.V., Kessler Park 1, 2288 GS

Rijswijk, The Netherlands

†To whom correspondence should be addressed. Jaap S. Sinninghe Damsté, NIOZ Royal Netherlands Institute for Sea Research, Department of Marine Organic Biogeochemistry, P.O. Box 59, 1790 AB Den Burg, Texel, The Netherlands. E-mail: jaap.damste@nioz.nl, phone number: +31 222-369550, fax number: +31 222-319674.
\end{abstract}

As published in: Geochim. Cosmochim. Acta 140, 106-126 (2014)

\begin{abstract}
The MBT/CBT palaeotemperature proxy uses the distribution of branched glycerol dialkyl glycerol tetraethers (brGDGTs), membrane lipids that are supposed to derive from soil bacteria, to reconstruct mean annual air temperature (MAAT). Applied successfully in coastal marine sediments, its extension to lake-sediment records with potentially high time resolution would greatly expand its utility. Over the last years, however, studies have indicated the presence of additional sources of brGDGTs within lake systems. To constrain the factors influencing the MBT/CBT palaeotemperature proxy in lakes, detailed investigation of brGDGT fluxes in a modern lake system is necessary to identify their potential sources. This study concentrates on Lake Challa, a permanently stratified crater lake in equatorial East Africa with limited catchment area. An almost 3-year time series of approximately monthly samples of settling particles, supplemented with a depth profile of suspended particulate matter (SPM) and sets of profundal surface-sediment and catchment soil samples, were analysed for both the 'living' intact polar lipids (IPLs) and 'fossil' core lipids (CLs) of GDGTs. We found that brGDGTs are produced in oxic, suboxic and anoxic zones of the water column, and in substantial amounts compared to influxes from catchment soils. Additional in-situ production within the lake sediments is most probable, but cannot be definitely confirmed at this time. These lacustrine brGDGTs display a different response to temperature variation than soil-derived brGDGTs, signifying either a different physiological adaptation to changing conditions within the water column and/or a different composition of the respective bacterial communities. Using this specific relationship with temperature, a local calibration based on brGDGT distributions in SPM generates relatively accurate water temperature estimates from settling particles but fails for surface sediments.
\end{abstract}




\section{INTRODUCTION}

Branched glycerol dialkyl glycerol tetraethers (brGDGTs) are bacterial membrane lipids found universally in soils all over the world, and are presumed to be produced by bacteria living in anaerobic microniches within those soils (Weijers et al., 2006a,b; 2007a). Originally identified in peat (Sinninghe Damsté et al., 2000), a detailed study of an ombrotrophic peat bog postulated that brGDGTs may be produced by members of the Acidobacteria phylum, based upon correlation between brGDGT abundance and Acidobacteria proliferation (Weijers et al., 2009). Recently, presence of the uncyclised brGDGT with four methyl substituents (GDGT-I, Appendix) has been confirmed in cultured strains of subdivision-1 aerobic Acidobacteria (Sinninghe Damsté et al., 2011). The structurally more complex brGDGTs found in soils derive from as yet unidentified bacteria, potentially also members of the Acidobacteria phylum.

In an analysis of brGDGTs from a large global soil dataset, Weijers et al. (2007a) observed that different soils contained different distributions of individual brGDGTs, which vary in the degree of cyclisation and methylation of their ether-bound hydrocarbon chains. This variation was quantified in the methylation index of branched tetraethers (MBT) and the cyclisation ratio of branched tetraethers (CBT), which were found to correlate with mean annual air temperature (MAAT) and soil pH (Weijers et al., 2007a). The mechanism underlying these correlations is thought to be brGDGT producing bacteria adapting their cell membrane to changing environmental conditions (Weijers et al., 2007a, and references therein). The MBT/CBT quantifications from the global soil dataset were calibrated to local modern-day MAAT, resulting in a quantitative MAAT proxy (Weijers et al., 2007a). This $\mathrm{MBT} / \mathrm{CBT}$ temperature proxy has since been applied in coastal marine sediments containing a large proportion of terrestrial organic matter, such as in close proximity to large river outflows (e.g. Weijers et al., 2007b,c; Schouten et al., 2008; Donders et al., 2009; Bendle et al., 2010; Keating-Bitonti et al., 2011; Pross et al., 2012). Recently, Peterse et al. (2012) expanded the MBT/CBT temperature calibration by increasing the Weijers et al. (2007) soil dataset from 134 to 278 globally distributed soils, and by using a revised ratio for the degree of methylation (MBT'). However, Peterse et al. (2012) emphasise that MBT'/CBT temperature relationships remain the same as with the original calibration.

To extend the utility of the MBT/CBT proxy to reconstruct past continental temperatures, it would be advantageous to expand its application to lacustrine sediment records. Deposition of eroded soil material in lake sediments may render the MBT/CBT proxy a useful tool for studying continental climate change in both high temporal resolution and on a spatially more detailed scale. Consequently, much recent research has explored the MBT/CBT proxy in lake sediments (Sinninghe Damsté et al., 2009, 2012; Tierney and Russell, 2009; Bechtel et al., 2010; Blaga et al., 2010; Tierney et al., 2010; Tyler et al., 2010; Zink et al., 2010; Loomis et al., 2011, 2012; Sun et al., 2011; Shanahan et al., 2013). From these studies, it has now become apparent that lakes can contain different brGDGT distributions than those found in the catchment soils that are their presumed source. As a result, temperature estimates based on brGDGT distributions in lake sediments can substantially deviate from measured values, in most cases providing unduly low estimates (e.g. Tierney and Russell, 2009; Blaga et al., 2010; Tierney et al., 2010). In an effort to improve the accuracy of reconstructed MAAT, several regional lake brGDGT-based calibrations have recently been developed, namely for tropical Africa (Tierney et al., 2010; Loomis et al., 2012), China and Nepal (Sun et al., 2011), New Zealand (Zink et al., 2010), and latitudinally from the Scandinavian Arctic to the Western Antarctic region (Pearson et al., 2011). 
It has been suggested that the mismatch between brGDGT distributions in catchment soils and lake sediments may be explained by additional in-situ production of brGDGTs in the water column or in profundal (deep-water bottom) sediments (Sinninghe Damsté et al., 2009; Tierney and Russell, 2009; Blaga et al., 2010; Tierney et al., 2010; Loomis et al., 2012). Confirming or disproving this hypothesis poses a problem, as the bacteria that produce brGDGTs have not yet been fully characterised (Sinninghe Damsté et al., 2011), preventing direct microbiological screening of living biomass extracted from possible source environments. Previous studies (e.g. Tierney and Russell, 2009; Sinninghe Damsté et al., 2009; Blaga et al., 2010) mostly looked at the distributions of individual brGDGTs to resolve their sources. Tierney et al. (2012) also looked at the intact polar lipids (IPLs) of brGDGTs in pond sediments and watershed soils to differentiate between brGDGTs contained in (presumably) locally living bacteria and 'fossil' brGDGTs released by degradation.

Lake Challa, East Africa, provides a convenient setting to study in detail the fluxes and distributions of brGDGTs in a modern lake system. Noting different CL brGDGT distributions in catchment soils relative to those found in settling material, suspended particulate matter and recently deposited bottom sediments, Sinninghe Damsté et al. (2009) suggested that in-situ production of brGDGTs may be occurring in the water column and/or bottom sediments of Lake Challa. If so, the nature of Lake Challa as a moderately deep lake (ca. $90 \mathrm{~m}$ ) with very small catchment area would present a most suitable system to study these in-situ produced brGDGTs, as any autochthonous brGDGT signal would be less likely to be overwhelmed by brGDGT input from surrounding soils. In-situ brGDGT production in Lake Challa has obvious implications for the application of the MBT/CBT palaeotemperature proxy to the valuable tropical climate archive stored in its sediments, and potentially those of other lakes. In this study, we analyse brGDGTs in a full range of samples from within and outside the catchment of Lake Challa, its water column and recent bottom sediments, using IPLs to help constrain the fluxes and sources of brGDGTs in this tropical lake system.

\subsection{Study site}

\section{MATERIALS AND METHODS}

Lake Challa is a $4.2 \mathrm{~km}^{2}, 92 \mathrm{~m}$ deep crater lake in equatorial East Africa $\left(3^{\circ} 19^{\prime} \mathrm{S}\right.$, $37^{\circ} 42$ 'E; Fig. 1). The lake is situated in a volcanic caldera at $880 \mathrm{~m}$ elevation on the southeastern flank of Mt. Kilimanjaro. Its crater catchment of just $1.38 \mathrm{~km}^{2}$ consists entirely of steep crater walls reaching up to $170 \mathrm{~m}$ above the lake surface, and is marginally enlarged to $1.43 \mathrm{~km}^{2}$ during periods of exceptional rainfall when a $300-\mathrm{m}$ creek breaching the north-west corner of the crater rim is activated (Sinninghe Damsté et al., 2009; Verschuren et al., 2009).

The biannual passage of the Intertropical Convergence Zone (ITCZ) over Lake Challa normally results in a bimodal seasonal distribution of precipitation, with 'long rains' from March to mid-May and 'short rains' from late October to mid-January (Fig. S1), however much inter-annual variation exists in the timing and relative prominence of these two rain seasons. Lowest mean night-time and daytime temperatures, as recorded in the nearby town of Voi, occur in July-August (ca. 18 and $28{ }^{\circ} \mathrm{C}$, respectively), and highest in February-March (ca. 21 and $33{ }^{\circ} \mathrm{C}$, Buckles et al., 2013; Fig. S1). Daytime maxima near the lake (courtesy of A. Hemp, University of Bayreuth) are milder, by up to $5{ }^{\circ} \mathrm{C}$ (Fig. 2). Lake Challa is hydrologically open, its water level being partly controlled by sub-surface outflow (annually ca. $2.5 \%$ of lake volume; Payne, 1970) through the porous upper crater walls, mostly towards the east. Sub-surface inflow derives mainly from precipitation falling on the montane forest of Mt. Kilimanjaro at 1800-2800 m elevation (Hemp, 2006), and is responsible for ca. $80 \%$ of 
hydrological inputs. The water budget is balanced by local precipitation (ca. $600 \mathrm{~mm} \mathrm{yr}^{-1}$ ) and lake-surface evaporation (ca. $1700 \mathrm{~mm} \mathrm{yr}^{-1}$; Payne, 1970).

Lake Challa is most probably permanently stratified (meromictic), meaning that mixing of the entire water column does not occur on (inter-) annual or even decadal time scales (Verschuren et al., 2009). Daily, wind-driven mixing reaches to 15-20 m depth while deep seasonal mixing between July and September, when surface water temperatures drop to ca. 23 ${ }^{\circ} \mathrm{C}$, extends to between 45 and $60 \mathrm{~m}$ depth. The water column below $60 \mathrm{~m}$ keeps a constant $22.3{ }^{\circ} \mathrm{C}$ and has a slightly elevated dissolved-ion content, which hampers deep convective mixing. Surface waters reach a maximum of ca. $28{ }^{\circ} \mathrm{C}$ in April. During the long stratified period from October through June, anoxic conditions expand upwards from 45-60 m to ca. 30 $\mathrm{m}$ water depth (Kristen, 2009). The lake has a Secchi disk transparency of between 5 and $7 \mathrm{~m}$, implying modest aquatic productivity. Lake Challa's profundal bottom sediments are laminated, dominated by the deposition of biogenic silica from diatom blooms during the cooler months of deep mixing and of organic matter and calcite laminae in the warmer months of austral summer (Barker et al., 2011; Wolff et al., 2011).

\subsection{Sample collections}

2.2.1 Water column. Water column temperature, $\mathrm{pH}$ and dissolved oxygen were measured along a vertical profile at an offshore location in Lake Challa (Fig. 1) on February 1, 2010. These variables were measured in situ every metre from the surface to $50 \mathrm{~m}$ depth using a Hydrolab Quanta multi-sensor (CTD) instrument. Deeper measurements, at every $5 \mathrm{~m}$ from 50 to $85 \mathrm{~m}$ and finally just above the profundal lake bottom at $89.4 \mathrm{~m}$ depth, were made ex situ on water samples brought to the surface with a 2-liter Hydrobios sampler. This process inevitably causes some heating and injection of oxygen; consequently we assume that dissolved oxygen was $0.0 \mathrm{mg} / 1$ throughout the lower water column, as measured in situ between 45 and $50 \mathrm{~m}$ (Fig. 3B), and on several earlier occasions (e.g., Barker et al., 2013) with a different CTD instrument measuring in situ at greater depth. We also replace the ex situ deep-water temperature readings with those recorded on that date by the automatic temperature loggers (Figs. 2, 3A).

Using the Hydrobios sampler, a vertical profile of suspended particulate matter (SPM) from the water column of Lake Challa was obtained on February 3, 2010, retrieving ca. 6 liter of water at $5 \mathrm{~m}$ intervals from the surface to $30 \mathrm{~m}$ depth, then every $10 \mathrm{~m}$ to $80 \mathrm{~m}$ depth, and finally at $82.5 \mathrm{~m}, 85 \mathrm{~m}$ and $89.4 \mathrm{~m}$. The collected water was filtered onto ashed $\left(300{ }^{\circ} \mathrm{C}, 10 \mathrm{~h}\right)$ glass fibre filters (Whatmann $\mathrm{GF} / \mathrm{F}$; pore size $0.7 \mu \mathrm{m}$ ) within $9 \mathrm{~h}$ of collection. The filters were frozen immediately and then stored frozen until processing for geochemical analysis in the laboratory.

2.2.2 Sediment trap time series. A sediment trap with a surface area of $58 \mathrm{~cm}^{2}$ was suspended at $35 \mathrm{~m}$ depth in the centre of Lake Challa in November 2006. In a continuous series of approximately monthly recoveries of sediment trap material, 33 consecutive months of settling particles were sampled from December 2007 to August 2010. Collected material was left to stand for two days or until all particulates had settled, after which excess water was decanted off and samples were stored frozen. In the laboratory the samples were thawed and filtered onto ashed glass fibre filters (Whatmann $\mathrm{GF} / \mathrm{F}$; pore size $0.7 \mu \mathrm{m}$ ) prior to extraction.

2.2.3 Profundal surface sediments. Twenty-four surface-sediment samples were collected between January 25 and February 5, 2010 from across the profundal lake bottom at water depths ranging from 32.8 to $91.6 \mathrm{~m}$ (Fig. 1). No fine-grained sediment could be retrieved from 
shallower depths, given the steep rocky slopes encircling the lake down to at least $50 \mathrm{~m}$ in most places (Fig. 1, cf. Moernaut et al., 2010). All surface samples were recovered with intact sediment-water interface using an UWITEC gravity corer and extruded vertically to collect the $0-1 \mathrm{~cm}$ depth interval. In cores with visible bacterial mats at the sediment surface $(\mathrm{CH} 10-$ $16 \mathrm{G}$ and $\mathrm{CH} 10-25 \mathrm{G}$ ), depth intervals $0-0.5$ and $0.5-1 \mathrm{~cm}$ were stored separately. All samples were kept cool for several days and then frozen until analysis.

2.2.4 Lake sediment profile. The longer gravity core $\mathrm{CH} 08-1 \mathrm{G}$ from near the deepest point of Lake Challa (Fig. 1) was extruded on-site at $0.5 \mathrm{~cm}$ intervals and stored frozen within $12 \mathrm{~h}$ of its collection. A selection of available depth intervals were subsampled: all intervals from $0-5$ $\mathrm{cm}$, and then at 7-7.5, 9-9.5, 11-11.5 and 13-13.5 cm depth.

2.2.5 Soils. Thirty-two soil samples were taken at various locations along the mostly forested lake shore (L), from within the small ravine near the lake (R), from the grassy upper crater rim (C), and extending outside of the crater in the 'hinterland' region of the rim-breaching creek $(\mathrm{H})$ in the north-west corner of the catchment (Fig. 1). In addition, four sediment samples were collected from two dry stream beds on the lower east slope of Mt. Kilimanjaro $(\mathrm{H})$, several kilometres to the northwest of Lake Challa (locations not shown in Fig. 1). 'Shared' origins are indicated by a combination of these letters; for example, LR denotes a soil sampled at the lakeshore in the vicinity of the ravine. Soils are further categorised as either red (lateritic) or grey (volcanic) types. Soils were sampled over the ca. 0-10 cm depth interval using a trowel, if necessary after removal of vegetation and litter. In the lab, every effort was made to remove small leaf litter and wood fragments, however it is possible that small remaining fragments contributed to the high $\% \mathrm{C}_{\text {org }}$ value of some soil samples.

\subsection{Geochemical analysis}

2.3.1. Elemental analysis. A small subsample of each soil and lake surface sediment sample was subjected to carbonate removal using dilute $(1 \mathrm{~N})$ hydrochloric acid and analysed for total organic carbon content $\left(\mathrm{C}_{\text {org }}\right)$ on a Fisons NA1500 NCS elemental analyser (EA) using the normal Dumas combustion method.

2.3.2. GDGT analysis. Soils, filtered sediment trap material, SPM, and lake sediments were freeze-dried and extracted using a modified Bligh and Dyer procedure (Bligh and Dyer, 1959). Typically, 7-10 g dry mass of soil, ca. $0.1 \mathrm{~g}$ of lake sediment and half of each sediment trap and SPM sample (approximate dry weight ranging from near zero to $0.25 \mathrm{~g}$ ) were prepared for GDGT analysis. Samples were ultrasonically extracted three times with a known volume of monophasic solvent mixture, consisting of methanol: dichloromethane (DCM): phosphate buffer in a ratio of 2:1:0.8 (v/v/v). The supernatant was collected and its composition altered to methanol: DCM:phosphate buffer 1:1:0.9 (v/v/v) to bring about phase separation. The aqueous mixture was extracted three times with DCM. The extract was then rotary evaporated to near dryness and transferred to a pre-weighed vial through pre-extracted cotton wool. Bligh-Dyer extracts were separated into intact polar lipid (IPL) and core lipid (CL) fractions using column chromatography with activated silica gel stationary phase (Pitcher et al., 2009). The CL fraction was eluted with $5 \mathrm{ml}$ hexane: ethyl acetate $1: 1(\mathrm{v} / \mathrm{v})$ and the IPL fraction was eluted with $5 \mathrm{ml}$ methanol. A known amount of $\mathrm{C}_{46}$ GDGT internal standard was added for quantification (Huguet et al., 2006) and fractions were dried under a nitrogen atmosphere. Prior to hydrolysis, $10 \%$ of each IPL fraction was removed and analysed for CLs, to determine the efficacy of the column separation. Carry-over of CLs into the IPL fraction upon column separation accounted for less than $3 \%$ of the brGDGTs present in the 
IPL fraction for soils and up to $6 \%$ for SPM. The remaining $90 \%$ of the IPL fraction was acid hydrolysed to cleave the polar head groups from the GDGT core lipids by refluxing in $1.5 \mathrm{~N}$ $\mathrm{HCl} / \mathrm{MeOH}$ solution for $2 \mathrm{~h}$, followed by an aqueous work-up. The $\mathrm{pH}$ of the resulting mixture was brought up to $\mathrm{pH}$ 4-5 and extracted three times with DCM. Hydrolysed IPL (HIPL) fractions were dried over anhydrous $\mathrm{Na}_{2} \mathrm{SO}_{4}$ columns and IPL GDGTs were analysed as their CL derivatives.

CL, IPL and H-IPL fractions were dissolved in hexane: isopropanol 99:1 (v/v) and passed through $0.45 \mu \mathrm{m}$ polytetrafluoroethylene (PTFE) filters prior to analysis by high performance liquid chromatography-atmospheric pressure chemical ionisation/mass spectrometry (HPLCAPCI/MS). These analyses took place on an Agilent 1100 series HPLC connected to a Hewlett-Packard 1100 MSD SL mass spectrometer using the methodology described by Schouten et al. (2007). Selected ion monitoring (SIM) detection of the $(\mathrm{M}+\mathrm{H})^{+}$ions of GDGTs was used in conjunction with HP Chemstation software for quantification; a crenarchaeol: $\mathrm{C}_{46}$ GDGT standard mixture was run regularly to check and compensate for differences in ionisation efficiencies.

GDGT distributions in the samples were quantified using the following indices (see Appendix for structures):

$$
\begin{aligned}
& \text { BIT index }=\frac{[I]+[I I]+[I I I]}{[I]+[I I]+[I I I]+[\text { Cren } .]} \\
& M B T=\frac{[I]+[I b]+[I c]}{[I]+[I b]+[I c]+[I I]+[I I b]+[I I c]+[I I I]+[I I I b]+[I I I c]} \\
& M B T^{\prime}=\frac{[I]+[I b]+[I c]}{[I]+[I b]+[I c]+[I I]+[I I b]+[I I c]+[I I I]} \\
& D C=\frac{[I b]+[I I b]}{[I]+[I b]+[I I]+[I I b]} \\
& C B T=-\log _{10}\left(\frac{[I b]+[I I b]}{[I]+[I I]}\right)
\end{aligned}
$$

The Branched vs. Isoprenoid Tetraether (BIT) index, expressing the relative abundances of brGDGTs and the isoprenoid GDGT crenarchaeol, is often used as a tracer for terrestrial vs. aquatic organic matter in sediments, based on the supposedly exclusive origin of brGDGTs in soils (Hopmans et al., 2004). The DC index is, like the CBT ratio, a measure of the degree of cyclisation of brGDGTs. The DC index was defined by Sinninghe Damsté et al. (2009) in order to make it more directly comparable with the MBT index, by omitting the log-function used in the CBT. The CBT ratio can be translated into a $\mathrm{pH}$ estimate using the soil-based calibration of Peterse et al. (2012):

$p H=7.90-1.97 C B T$

MAAT can also be estimated using the MBT' and CBT indices from the expanded soil calibration by Peterse et al. (2012):

$M A A T=0.81-5.67 C B T+31.0 M B T^{\prime}$

However, here we refer to MBT rather than MBT' since due to the low abundances of GDGTs IIIb-c in these tropical soils, the two indices are virtually identical (difference is 0.005 or less). Where we present soil-based MAAT estimates using the Peterse et al. (2012) calibration, these are nevertheless calculated using MBT' to ensure accuracy. 
MAAT estimates from lake sediments were derived using the original 46-site African lakebased calibration of Tierney et al. (2010):

$M A A T=50.47-(74.18 \times f[I I I])-(31.60 \times f[I I])-(34.69 \times f[I])$

and compared to MAAT estimates derived using the expanded African lake-based calibration of Loomis et al. (2012):

$M A A T=-22.77-(33.58 \times f[I I I])-(12.88 \times f[I I])-(418.53 \times f[I I c])+(86.43 \times f[I b])$

where $f()=$ fractional abundance of the indicated GDGTs.

The proportion of intact polar lipids is expressed as:

$\% I P L=\left(\frac{[H-I P L]}{[H-I P L]+[C L]}\right) \times 100$

where [H-IPL] denotes the hydrolyzed intact polar lipid concentration and [CL] the core lipid concentration.

2.3.3. Statistical analysis. In order to understand the brGDGT distributions and abundances in soil fluxes to Lake Challa, a Ward hierarchical agglomerative cluster analysis (using $\mathrm{R}$ version 2.15.0) was performed on soil samples, based on the concentration of total CL brGDGTs, the MBT, CBT and BIT indices, and $\% \mathrm{C}_{\text {org }}$. IPL GDGTs were excluded from this analysis because of the less comprehensive data set.

\subsection{Soils}

\section{RESULTS}

Soils from within the catchment of Lake Challa (the inner crater slopes plus 'hinterland' around the ravine breaching its north-west corner) and from the nearby lower flank of Mt.Kilimanjaro are relatively dry and heterogeneous, with $\mathrm{C}_{\text {org }}$ content ranging from 0.6 to $24.7 \%$ (Table S1). When separated by location (H, R, C, L and combinations thereof) and soil type (red lateritic versus grey volcanic), systematic differences in the distributions (Fig. 3AB) and concentrations (Table S1) of brGDGTs become apparent. Cluster analysis (see methods) discriminates four groups of soils (Table S1). Cluster 1 contains red soils from the hinterland (including near the ravine) and cluster 2 contains only red ravine soils (two from the lakeshore below the ravine and one from a sheet-wash area in the ravine). Cluster 3 is made up of grey or mixed grey/red crater rim soils, plus three red soils (among which one from the crater rim in the ravine area) that share their intermediate MBT values, high CBT ratios, intermediate BIT indices and low brGDGT concentrations (Table S1). Cluster 4 contains predominantly volcanic soils from the crater rim and the lakeshore. The organic carbon content is relatively low in soil clusters 1,2 and 3 ( 0.5 to $4.1 \%$; Table S1); six (near-) lakeshore soils in cluster 4 exhibit much higher $\% \mathrm{C}_{\text {org }}$ values of 6.9 to $24.7 \%$. All these soils are either from relatively densely forested lakeshore areas or receive run-off from them.

When normalised to $C_{\text {org }}$, the lowest observed CL brGDGT concentration is $1.2 \mu \mathrm{g} \mathrm{g}^{-1}$ $\mathrm{C}_{\text {org }}$, found in one soil from cluster 1 and two from cluster 4 (Table S1). While most soils contain CL brGDGT concentrations $<5 \mu \mathrm{g} \mathrm{g}^{-1} \mathrm{C}_{\mathrm{org}}$, cluster 2 contains the three soils with higher concentrations (6.6 - $10.9 \mu \mathrm{g} \mathrm{g}^{-1} \mathrm{C}_{\text {org }}$; Table S1). Seven soils from different locations and soil types were analysed for IPL brGDGTs. The proportion of IPL vs. CL brGDGTs (\%IPL) varies from 5 to $16 \%$ and shows no clear trend among the clusters (Table S1). Distributions of IPL and CL brGDGTs in individual soil samples are mostly similar (Table S1). Distinct variation in both brGDGT concentration (Table 1) and distribution (Table 2, Figs. 4A-D) occurs within the various soil clusters. Within cluster 1, CL MBT values range 
from 0.69 to 0.83 with an average of 0.75 ; in cluster 2 , from 0.53 to $0.67(\bar{x}=0.57)$; in cluster 3 , from 0.48 to $0.66(\bar{x}=0.56)$; and in cluster 4 , from 0.42 to $0.54(\bar{x}=0.49)$. CL CBT values in cluster 1 range from 0.51 to $1.13(\bar{x}=0.88)$; in cluster 2 , from 0.35 to $0.49(\bar{x}=0.44)$; in cluster 3, from 0.53 to 0.97 ( $\bar{x}=0.71)$; and in cluster 4 , from 0.41 to $0.68(\bar{x}=0.54)$. IPL BIT indices are far lower than CL BIT values (Table 2). Although the soils generally contain higher concentrations of CL brGDGTs than CL crenarchaeol, crenarchaeol exhibits generally higher \%IPL values (from 24 to 80\%) than the brGDGTs (from 5 to $16 \%$; Table S1). This results in a considerably lower mean BIT index for IPL GDGTs in all soil clusters, ranging from 0.16 to 0.41 (Table S1).

\subsection{Water column: suspended particulate matter}

The brGDGT concentrations in SPM vary widely through the water column (Fig. 5D). Both CL and IPL brGDGT concentrations increase substantially below $24 \mathrm{~m}$ depth; CL brGDGTs range from $0.3-0.4 \mathrm{ng}^{-1}$ in daily mixed, well-oxygenated water above the principal thermocline to $18 \mathrm{ng} \mathrm{l}^{-1}$ just above the lake bottom (Table S2). IPL brGDGTs are lower in concentration than CL brGDGTs, reaching a modest peak at $49 \mathrm{~m}$ depth, and near the bottom IPL brGDGT concentrations do not increase to the same extent as those of CL brGDGTs. The proportion of IPL brGDGTs relative to total brGDGTs (\%IPL; Fig. 5I) increases from below detection limit at the surface to $34 \%$ in upper anoxic waters at $49 \mathrm{~m}$ depth, then declines to $11 \%$ in the deepest part of the water column as CL brGDGTs increase (Fig. 5D). The exceptions to this trend are a peak of $45 \%$ IPL at $9 \mathrm{~m}$ depth and a smaller increase at $86 \mathrm{~m}$.

All abundance-weighted index and ratio means for six major sections of the water column are listed in Table 2 . These sections are subdivided by the following criteria: fully oxygenated with constant temperature and $\mathrm{pH}$ ( 0 to $20 \mathrm{~m}$; five samples); predominantly sub-oxic at depths around and below the principal thermocline (21 to $45 \mathrm{~m}$; three samples); anoxic but most likely turning over annually (46 to $60 \mathrm{~m}$; two samples); permanently anoxic except for isolated deep mixing events, demarcated by decreasing $\mathrm{pH}$ and increasing conductivity with depth (61 to $70 \mathrm{~m}$; one sample); permanently anoxic with stable $\mathrm{pH}$ and conductivity (71 to $85 \mathrm{~m}$; three samples); and immediately above the sediment-water interface (here at $89.4 \mathrm{~m}$; one sample) (Fig. 5). The BIT indices of CL and IPL GDGTs in SPM are similar and vary from 0.53 to 0.95 (CL) and 0.48 to 0.97 (IPL; Table S2). Values are lowest at the oxycline and highest at and below $49 \mathrm{~m}$ depth. The average distributions of CL and IPL brGDGTs in SPM are similar (Fig. 4E) but they vary widely through the water column, as reflected by variable MBT and CBT values (Figs. 5F-G). CL MBT indices range from a minimum of 0.11 in the lowermost oxygenated waters at $39 \mathrm{~m}$ depth and $0.15-0.25$ in the anoxic lower water column to 0.44 in near-surface waters, while CBT ratios vary from 0.30 in the daily-mixed surface layer and 0.6-0.7 in the anoxic lower water column to a peak of 1.27 at $39 \mathrm{~m}$ depth; IPL MBT and CBT values show similar patterns. Sinninghe Damsté et al. (2009) analysed CLs in an SPM profile from September 2006, during or shortly after an episode of deep seasonal mixing when water column temperature varied little from top to bottom (22.2-23.2 ${ }^{\circ} \mathrm{C}$ ). MBT values at that time ranged from 0.20 to 0.46 (lowest values at 50 and $60 \mathrm{~m}$ depth, highest at $10 \mathrm{~m}$ ) and CBT from 0.36 to 0.76 (lowest at $5 \mathrm{~m}$, highest at $20 \mathrm{~m}$ ) (Figs. 5L-M).

\subsection{Water column: settling particles}

The bulk flux of sedimenting material co-varies with that of $\mathrm{C}_{\text {org }}$ through 33 monthly observations between December 2007 and the end of August 2010 (Fig. 2C). CL brGDGT fluxes range from 0-12.0 $\mu \mathrm{g} \mathrm{m}^{-2}$ day $^{-1}$, peaking in December 2008 (Fig. 2D). IPL brGDGT fluxes also peak in December 2008 at $2.2 \mu \mathrm{g} \mathrm{m}^{-2}$ day $^{-1}$. The \%IPL of brGDGTs collected in 
the sediment trap fluctuates between 7 and 54\% (Table S3), but does not display any clear trends throughout the period of observation. The flux-weighted mean of $20 \pm 11 \%$ is identical to the value found for SPM (Table 1). Crenarchaeol fluxes are generally lower than brGDGT fluxes and do not show similar trends (Fig. 2E). Peaks in CL crenarchaeol fluxes occur in December 2007 (3.4 $\mathrm{g} \mathrm{m} \mathrm{m}^{-2}$ day $\left.^{-1}\right)$ and April $2010\left(4.0 \mu \mathrm{g} \mathrm{m}^{-2}\right.$ day $\left.^{-1}\right)$; these coincide with maxima in IPL crenarchaeol fluxes. The proportion of crenarchaeol IPLs to CLs shows no obvious trends, ranges from 4 to $43 \%$ (Table S3), and has a flux-weighted mean of $19 \pm 11 \%$ (Table 1).

CL and IPL GDGTs in settling particles yield similar BIT values, but they show substantial temporal variation with lower BIT values mostly co-occurring with elevated crenarchaeol fluxes (Fig. 2F). The CL and IPL fractions of brGDGTs in settling particles also yield similar MBT and CBT values throughout the observed time period (Figs. 2G-H; Table S3), but again with substantial temporal variation in both MBT and CBT. The MBT of CL brGDGTs ranges from 0.13 in December 2008 to 0.50 in August 2008; the MBT of IPL brGDGTs ranges from 0.13 in December 2008 to 0.68 in July 2010. CL CBT values vary between 0.25 in July 2008 and 1.38 in December 2008; IPL CBT values between 0.19 in July 2010 and 1.65 in November 2008. This range of MBT and CBT values in both IPL and CL brGDGT distributions is larger than was found in the catchment soils, and comparable to that for the MBT and CBT in SPM.

\subsection{Lake bottom surface sediments}

Surface sediments $(0-1 \mathrm{~cm}$ depth) from the bottom of Lake Challa are homogeneously rich in organic matter $\left(\mathrm{C}_{\text {org }}=8.9 \pm 2.7 \%\right.$; Table 1$)$. Mean CL and IPL brGDGT concentrations are $87 \pm 31$ and $19 \pm 9 \mu \mathrm{g} \mathrm{g}^{-1} \mathrm{C}_{\text {org }}$, respectively; absolute $\mathrm{CL}$ and IPL brGDGT concentrations are 7.5 and $1.7 \mu \mathrm{g} \mathrm{g}^{-1}$ dry wt. The spatial distribution of CL brGDGT concentrations in surface sediments is relatively constant, with the exception of a single high value $\left(210 \mu \mathrm{g} \mathrm{g}^{-1} \mathrm{C}_{\text {org }}\right)$ in the southwest corner of the lake (Fig. S2A), which is not necessarily representative of the entire area. IPL brGDGT concentrations show a similar spatial distribution (Fig. S2B). The $\%$ IPL of brGDGTs in lake sediments ranges from 11 to $28 \%$ (Table S4; mean $18 \%$ ), i.e. higher than that of soils. The highest \%IPL values of $27-28 \%$ are reached at near-maximum depths of 91.3 and $90.4 \mathrm{~m}$, respectively, but this is not uniformly so (Fig. S2C). Overall, \%IPL of brGDGTs is only weakly correlated with depth $\left(\mathrm{r}^{2}=0.23\right)$, which is also true when samples from the oxic zone are omitted. Still, the mean \%IPL of sites $>85 \mathrm{~m}$ depth $(20 \pm 5 \%$, $\mathrm{n}=10)$ is higher than that of sites $<85 \mathrm{~m}$ depth $(16 \pm 2 \% ; \mathrm{n}=14)$. The mean concentration of CL crenarchaeol in surface sediments $\left(9 \pm 16 \mu \mathrm{g} \mathrm{g}^{-1} \mathrm{C}_{\text {org }}\right)$ is substantially lower than that of CL brGDGTs $\left(87 \pm 31 \mu \mathrm{g} \mathrm{g}^{-1} \mathrm{C}_{\text {org }}\right)$, while the \%IPL of crenarchaeol $(19 \pm 5 \%)$ is similar to the $\%$ IPL of total brGDGTs (Table 1). Consequently, the BIT index of both CL and IPL GDGTs in surface sediments is uniformly high across Lake Challa (Table S4) with mean values of 0.90 (range 0.68-0.98) for CL and 0.92 (range 0.72-0.99) for IPL (Table 2).

BrGDGT distributions in profundal surface sediments display high spatial homogeneity across the lake, varying relatively little within our set of 24 samples (circles in Fig. 3). The MBT and CBT values of IPL and CL brGDGTs are also similar (Fig. 4G; Table S4), with strong linear correlation between CL and IPL values of MBT $\left(r^{2}=0.88\right)$ and CBT $\left(r^{2}=0.92\right)$; in contrast, there is only weak linear correlation between MBT and CBT values for both IPL $\left(\mathrm{r}^{2}=0.27\right)$ and CL $\left(\mathrm{r}^{2}=0.25\right)$ brGDGTs. The highest MBT values (ca. 0.45) are found at the greatest depths near the centre of the lake, decreasing towards shallower depths at the periphery in both CL $\left(\mathrm{r}^{2}=0.50\right)$ and IPL $\left(\mathrm{r}^{2}=0.37\right)$ brGDGTs, with the notable exception of surface sediment in the middle of the lake (Table S4). MBT is also high in the shallowest 
sample from the north-west corner of the lake, near the creek inflow (CL: 0.45), whereas the CBT value there is low (CL: 0.35). CBT values are uniformly high across the lake floor, with lower values mostly concentrated in near-shore areas (Table S4).

\subsection{Lake bottom sediment profile}

The mean absolute concentrations of CL and IPL brGDGTs in the $13.5 \mathrm{~cm}$ long lakebottom sediment profile analysed here are $6.7 \pm 4.2$ and $2.7 \pm 1.2 \mu \mathrm{g} \mathrm{g}^{-1}$, respectively, while those of crenarchaeol are $2.7 \pm 2.7$ and $0.5 \pm 0.3 \mu \mathrm{g} \mathrm{g}^{-1}$. In the top $\mathrm{cm}$ of this core, absolute abundances of CL and IPL brGDGTs are 5.4 and $3.2 \mu \mathrm{g} \mathrm{g}^{-1}$ dry wt, comparable to those of surface sediment samples. The \%IPL of total brGDGTs (Fig. 6D) decreases down-core from $48 \%$ at the surface $(0-5 \mathrm{~cm}$ depth) to $19 \%$ at $7.5 \mathrm{~cm}$ and subsequently varies in the range of $20-30 \%$ (Table S5). BIT values (Fig. 6C) range from 0.52 to 0.90 (CL) and from 0.72 to 0.94 (IPL), peaking just below the sediment-water interface; IPL BIT values are consistently higher than CL BIT values. The MBT and CBT values of CL and IPL brGDGTs also show similar trends through the profile, with few exceptions (Figs. 6A-B). Highest MBT values (0.54) are observed just below the sediment-water interface $(0.5-1.5 \mathrm{~cm} \mathrm{depth})$, where the highest BIT values are observed, but otherwise remain low and reasonably stable at $0.38-0.48$ (standard deviation $(\sigma)=0.03$ ). With one exception (IPL brGDGTs from 3.5-4.0 cm), CBT ratios of both IPL and CL brGDGTs generally decrease in the first $10 \mathrm{~cm}$ (Figs. 6A-B). Below $6 \mathrm{~cm}$ depth, IPL CBT ratios are consistently higher than those derived from CL brGDGTs.

\section{DISCUSSION}

\subsection{Sources of branched GDGTs}

4.1.1. Soils as the presumed primary source of brGDGTs in lake sediments. With few exceptions (e.g. Niemann et al. 2012), differences in brGDGT distributions between lake sediments and adjacent terrestrial soils have now been observed at numerous sites, such as Lake Towuti, Indonesia (Tierney and Russell, 2009), several small lakes in western Uganda (Loomis et al., 2011), and a small pond in the US (Tierney et al., 2012). Using a relatively small soil dataset, Sinninghe Damsté et al. (2009) reported this same discrepancy between soils and sediments at Lake Challa, and speculated that this may point to an additional source of brGDGTs either from outside the area then sampled for soils, or in the water column or sediments of Lake Challa, making it necessary to further constrain fluxes to the lake system.

IPL GDGTs represent a small proportion (ca. 10\%) of the total GDGT pool in soils surrounding Lake Challa, and are expected to degrade to CLs during transport. This means that IPL GDGTs are a less significant source of brGDGT influxes to the lake. Consequently, unless otherwise stated all ratios and indices reported here for soils refer to CL GDGTs. BrGDGT concentrations and distributions are rather variable in the soils, as is the $\% \mathrm{C}_{\text {org }}$. Cluster analysis of soils based on $\% \mathrm{C}_{\text {org }}$, brGDGT concentrations, MBT, CBT and BIT values revealed 4 separate clusters that with few exceptions relate to the location of the soil samples (Table S1). Several environmental factors could underlie this clustering, including vegetation type, soil humidity, type of $\mathrm{C}_{\mathrm{org}}, \mathrm{pH}$, conductivity, etc. The number of soil samples and environmental data available at present is, however, inadequate to investigate this further. It may be noticed, nevertheless, that the generally lower BIT indices of very dry soils from the crater rim (Table S1) are in agreement with the recent findings of Dirghangi et al. (2013) in the USA and Yang et al. (2014) in China. In addition, the observed clustering of catchment soils implies that distributions and concentrations of brGDGTs entering the lake from outside will vary depending on where soil erosion is highest. This emphasises the importance of the 
northwest ravine in our dataset since it may transport relatively high volumes of red hinterland soils, uncommon inside the crater, to the lake during periods of exceptionally high precipitation. This could potentially affect brGDGT distributions in the lake sediments.

Several lines of reasoning based on data from this study, however, indicate that soils cannot form the sole source of branched GDGTs in Lake Challa. Firstly, concentrations of brGDGTs, both absolute and relative to $\mathrm{C}_{\text {org }}$ (Table 1), are one to two orders of magnitude higher in lake surface sediments than in any of the soils analysed. A similar difference in magnitude of $\mathrm{C}_{\text {org }}$-normalised concentrations between lake sediments and catchment soils was observed by Tierney and Russell (2009) in Lake Towuti, Indonesia. CL brGDGT concentrations of Lake Challa bottom sediments also do not appear to be higher near-shore or near the ravine mouth where soil influxes are likely the greatest (Fig. S2A, Table S4). This argues against a substantial influx of soil-derived CL brGDGTs from surrounding hill slopes and the ravine, implying that soil-derived brGDGTs are not responsible for the majority of brGDGTs found in Lake Challa bottom sediments.

Secondly, the \%IPL of brGDGTs in Challa surface sediments $(11-28 \% ; \bar{x}=18 \% ; n=26)$ is clearly higher than in the surrounding soils $(5-16 \% ; \bar{x}=7 \% ; n=5)$. Relatively low mean \%IPLs in mid-latitude arable and grassland soils have been attributed to a CL brGDGT soil residence time of ca. two decades (Peterse et al., 2010; Weijers et al., 2010). Since IPLs are thought to convert to CLs rapidly following cell lysis (Harvey et al., 1986), only a small portion of IPL GDGTs transported with eroded soils to lake sediments are expected to survive intact. Although the preservation potential of IPLs in sediments is being questioned (especially concerning the more resilient glycolipids, e.g. Schouten et al., 2010), the substantially higher \%IPLs found in Lake Challa sediments would not be possible if soils were the sole source of brGDGTs. Instead, high \%IPLs in sediments, SPM (abundance-weighted mean: 20\%) and settling particles $(20 \%)$ point to a substantial amount of brGDGT production within the water column and potentially also in the bottom sediments of Lake Challa.

Thirdly, BIT values of soils around Lake Challa are relatively low ( 0.74 on average) compared with many soils elsewhere (generally $>0.90$; e.g., Weijers et al., 2006b, 2007a; Sinninghe Damsté et al., 2008; Tierney and Russell, 2009; Loomis et al., 2011; Schouten et al., 2013), and significantly lower than the mean CL BIT value of Challa surface sediments (0.91; unpaired Student's t-test, $\mathrm{p}<0.00001, \mathrm{t}=5.17)$. Since crenarchaeol is demonstrably produced in Lake Challa (Buckles et al., 2013), as it is in most medium to large lakes (Blaga et al., 2009), this implies that more brGDGTs than crenarchaeol are added within the lake system itself. Additionally, BIT values of Challa surface sediments are spatially fairly uniform (Table S4); not even a known area of higher soil influx in the north-west corner of the basin produces a clear deviation from this pattern. This strongly suggests that brGDGT production within the lake outweighs even the relatively strong allochthonous brGDGT sources entering the lake system via the ravine.

Lastly, differences in brGDGT distributions between lake sediments and surrounding soils have been noted before, including for lake Challa (e.g. Sinninghe Damsté et al., 2009; Tierney and Russell, 2009; Loomis et al., 2011), and also in this study differences in the distribution of brGDGTs between profundal surface sediments and soils are apparent (Fig. 4, Table 2). With only few exceptions, all soils, especially those from the ravine, yield MBT values much higher than those from profundal sediments. This difference is less clear for CBT, but ravine soils do yield on average higher CBT ratios than profundal sediments. Notably, and specific to this study, also brGDGT distributions in both settling particles and SPM (February 2010) are markedly different to those found in catchment soils (Fig. 4). It is 
unlikely that the wide range of MBT and CBT values found in our 33-month time series of settling particles (Figs. 2G, H) would occur over one seasonal cycle in soils surrounding the lake (cf. a seasonal study of brGDGTs in temperate soils; Weijers et al., 2011). Instead, this points again to an additional source of brGDGTs within the water column of Lake Challa.

In summary, the data from this study strongly suggest that influxes of soil-derived brGDGTs to Lake Challa are not responsible for the majority of brGDGTs found in the lake's bottom sediments. It appears that the majority of brGDGTs found in Lake Challa sediments are produced in the water column and perhaps also in the sediments themselves.

4.1.2. A possible groundwater source of brGDGTs? The water balance of Lake Challa is maintained in large measure by sub-surface infiltration of groundwater (Payne, 1970), which in turn derives from rain percolating into forest soils on the higher slopes of Mt.Kilimnajaro. Carrying the molecular signature of these soils, that groundwater could feasibly be an additional source of brGDGTs to the water column and to sediments. However, brGDGT distributions in an altitudinal transect of Mt. Kilimanjaro soils (Sinninghe Damsté et al., 2008) are strikingly different (Fig. 3A) to those of Lake Challa samples. Particularly the CBT values of Mt. Kilimanjaro soils (1.28-1.83) are far higher than any found in Lake Challa sediments (0.35-0.75). In addition, an influx of soil organic matter via groundwater would not explain the high \%IPLs seen in bottom sediments (section 4.1.1). This excludes groundwater sourced from Mt. Kilimanjaro as a substantial supplier of soil-derived brGDGTs to Lake Challa sediments.

4.1.3 In-situ production of brGDGTs in the water column. Having concluded in section 4.1.1 that brGDGT production is occurring in the water column of Lake Challa, we now turn our attention to where and when in the water column brGDGT-producing bacteria could be living and from which depths brGDGTs may be exported to the lake sediment.

Evidence from particles settling in the trap mounted at $35 \mathrm{~m}$ depth shows that brGDGTs are produced within the upper, oxygenated part of the water column. To determine the extent of this production, we look at our SPM data beginning with the well-oxygenated upper water column, where relatively low concentrations of both IPL and CL brGDGTs occur (Fig. 5D). In the surface water, where IPL brGDGT concentrations are below the quantification level, abundance-weighted CL MBT and CBT values ( 0.42 and 0.33 , respectively) are sufficiently different from those in catchment soils ( 0.56 and 0.67 , respectively) to indicate an additional source and thus a degree of in-situ production even in surface waters.

In SPM from the predominantly sub-oxic zone below the primary thermocline (i.e., 20-45 $m$ depth), both IPL and CL brGDGT concentrations rise by an order of magnitude (Fig. 5D). This increase is accompanied by a negative shift in MBT and strong positive shift in CBT across the oxycline (Figs. 5F-G; compare with Fig. 5B), denoting a marked change in brGDGT distribution peaking at $39 \mathrm{~m}$ depth. In combination with generally high \%IPL values throughout the water column (Fig. 5I; with the exception of surface waters), this implies insitu brGDGT production concentrated within the low-oxygen niche $\left(\mathrm{O}_{2}<2 \mathrm{mg} \mathrm{l}^{-1}\right)$ between 35 and $43 \mathrm{~m}$ water depth, suggesting that the bacteria responsible for this brGDGT production thrive in low oxygen conditions.

In the deeper, anoxic part of the water column below $45 \mathrm{~m}$ depth, increasing CL brGDGT (but not IPL brGDGT) concentrations (Fig. 5D) likely reflects the increased residence time of brGDGTs in these less frequently mixed bottom waters, with accumulation over time resulting in high CL concentrations. Supporting this reasoning, still higher brGDGT 
concentrations are found in the (near-) permanently stratified lower water column below $60 \mathrm{~m}$ depth. The difference in MBT and CBT values between the anoxic and oxic parts of the water column, in combination with still high proportions of IPLs below the oxycline, suggests that in-situ brGDGT production extends into the anoxic deeper water column.

At the same time, mean MBT values of settling particles and of SPM from the oxic water column are closer to values observed in the lake's sediments than those from the anoxic water column (Table 2). Generally, most organic matter in profundal lake sediments is exported from the water column via large, rapidly sinking particles that originate primarily from the actions of larger biota, like grazing zooplankton, in the oxic water column (McCave, 1984). In the Black Sea, lack of a biological export mechanism within the deep anoxic water column is thought to be responsible for isoprenoid GDGT distributions and carbon isotopic compositions in underlying sediments to predominantly reflect values comparable to those in the upper water column (Schouten et al., 2001; Wakeham et al., 2003). Schouten et al. (2012) found a similar effect in isoprenoidal GDGTs from Lake Tanganyika, where comparison of sedimentary $\mathrm{TEX}_{86}$ and BIT indices with water column values revealed that sedimentary GDGTs were derived primarily from the oxic and suboxic water column. A similar biological export mechanism seems to be acting in Lake Challa. Abundance-weighted mean brGDGT concentrations in SPM from the fully mixed, well-oxygenated upper water column (0-23 $\mathrm{m}$ at the time of SPM sampling in February 2010: 0.4 and $0.1 \mathrm{ng} \mathrm{l}^{-1}$ for CL and IPL; $\mathrm{n}=3$ ) is low compared with those from the oxic-anoxic transition zone (23-44 m: 3.3 and $0.6 \mathrm{ng}^{-1}$ for CL and IPL; $n=2$ ), suggesting that of the brGDGTs that eventually make it to the lake's bottom sediments, the majority is likely derived from the oxic-anoxic transition zone. We do note, however, that this SPM profile only represents a seasonal snapshot of the water column and that the present sampling occurred during a bloom of Thaumarchaeota peaking at ca. $40 \mathrm{~m}$ depth (Buckles et al., 2013; Fig. 2E). High brGDGT concentrations in the suboxic zone were not apparent after seasonal mixing of the lake in September 2006 (Fig. 5J).

It is also important to know when in the course of the year the brGDGT-producing organisms are most prolific, since this may affect the mean temperature 'recorded' by their brGDGT membrane lipids. Over the nearly three years of particles settling at $35 \mathrm{~m}$ depth covered by this study, IPL and CL brGDGT fluxes are consistently low, with the exception of the prominent peak between November 2008 and February 2009 (Fig. 2D). This season is notable for the absence of the peak crenarchaeol flux that occurs typically between January and March (Fig. 2E; Sinninghe Damsté et al., 2009). As has been observed in other settings (Wuchter et al., 2005; Pitcher et al., 2011), the thaumarchaeotal bloom in Lake Challa occurs after the annual phytoplankton bloom (Buckles et al., 2013). We speculate that unusual conditions in the water column during this atypically dry period in late 2008 and early 2009 may have suppressed the annual thaumarchaeotal bloom and encouraged a brGDGTproducing bacterial bloom instead. The distribution of brGDGTs during this high settling flux event (MBT $\sim 0.2$, CBT $\sim 1.4$; Fig. 2) is similar to that in SPM from suboxic water during February 2010 (Fig. 5). Beyond this observation, the nearly 3-year time series is still too short to properly indicate whether this event truly represents an unusual occasion or if it is part of natural inter-annual variability in this lake system.

Based on our data it is clear that brGDGTs are produced within the water column of Lake Challa, ostensibly in greater amounts than influxes of soil-derived CL brGDGTs over the studied time period. BrGDGT-producing bacteria seem to have an affinity for the sub-oxic zone of the water column. Enhanced preservation of both IPL and CL GDGTs in the lower anoxic water column combined with lack of a local export mechanism appears to lead to the accumulation of in-situ produced brGDGTs below the oxycline. 
4.1.4. BrGDGT production in sediments. Tierney et al. (2012) suggested that the occurrence of more highly methylated brGDGTs in the bottom sediments of the small $\left(0.05 \mathrm{~km}^{2}\right)$, shallow $(8 \mathrm{~m})$ Sand Pond (RI, USA) may reflect production within those sediments. Quantifying the amount of sedimentary brGDGTs potentially produced within the lake sediments themselves, relative to the water column, is important to constrain applications of the MBT/CBT palaeothermometer. If the brGDGTs are produced mainly within the sediment, their distributions would reflect annual mean bottom-water conditions, whereas production in the water column would relate their distribution to the conditions prevailing at the depth and season of production.

If brGDGT export from the sub-oxic water column is responsible for the bulk of brGDGTs reaching sediments, brGDGT distributions in sediments should be similar to those in particles settling at $35 \mathrm{~m}$ depth. Uncompacted profundal surface sediments $(0-1 \mathrm{~cm})$ represent 2-3 years of deposition prior to their sampling in January 2010 (Sinninghe Damsté et al., 2009; Wolff et al., 2011), suggesting that if sedimentary production is non-existent or negligible, the sedimentary signature should resemble the combined signature of about two years of settling particles prior to the sediment sampling date; here we refer to sediment-trap data for the period from 31/12/2007 to 27/12/2009. The mean \%IPL of brGDGTs in the surface sediments of Lake Challa (18\%) is high, and similar to those in settling particles (20 $\%$ ) and in SPM from February 2010 (16.7\% above $45 \mathrm{~m}$ and $20.1 \%$ below $45 \mathrm{~m}$ ). Since IPL brGDGTs produced in the water column, especially in its upper oxygenated part, are thought to degrade quickly following cell death (cf. Harvey et al., 1986), the high \%IPL of surfacesediment brGDGTs are one reason to suspect in-situ production of brGDGTs in sediments. However, this deduction is contingent on \%IPL values being a trustworthy tracer of living cells, which is currently disputed due to unresolved questions about the lability of glycolipids (Bauersachs et al., 2010; Schouten et al., 2010, 2012; Lengger et al., 2012). The possible resistance of IPLs to rapid hydrolysis in sediments, especially under anoxic conditions, precludes concluding definitively that brGDGT production in the sediments is responsible for their high \%IPL.

The mean BIT indices of settling particles (CL: 0.82; IPL: 0.76) are lower than those of surface sediments (CL: 0.90; IPL: 0.92), indicating an increased proportion of brGDGTs in sediments, relative to crenarchaeol, compared with the material exported from above $35 \mathrm{~m}$ depth. Since peak SPM crenarchaeol concentrations were found at ca. $45 \mathrm{~m}$ (at least in February 2010; Buckles et al., 2013), this is suggestive of a brGDGT source below the depth of the sediment trap. However, brGDGT production is demonstrated to occur in the water column below $35 \mathrm{~m}$ depth (see section 4.1.3) and could potentially be exported to sediments from the lower sub-oxic zone (above $45 \mathrm{~m}$ depth in February 2010).

To assess the likelihood of brGDGT production within the sediments, it is necessary to look at brGDGT distributions. Mean MBT values for CL and IPL brGDGTs in settling particles (Figs. 4F-G: 0.24 and 2.27) are lower than those in surface sediments (Table 2, Figs. 3A-B: 0.34 and 0.33). Mean CBT values for IPL brGDGTs are essentially identical in surface sediments (0.72) and setting particles (0.73), whereas CL brGDGTs have slightly higher CBT values in settling particles (0.72) than in surface sediments $(0.65)$. These differences in brGDGT distribution indicate that a proportion of the brGDGTs found in sediments does not originate exclusively from settling particles originating above $35 \mathrm{~m}$ depth. Additional influx of brGDGTs with different distributions from the water column below $35 \mathrm{~m}$ depth is improbable, since to balance out the low upper water column MBT values, their MBT values need to be considerably higher than 0.35 , which is not the case (Fig. 5F). Additionally, lake 
sediment MBT and CBT values lie between those of soil and settling particles/SPM (Figs. 3A-B). Since brGDGTs derived from soils contribute an insignificant proportion of the total brGDGTs exported to sediments (see sections 4.1.1; 4.1.3), the shift in sedimentary brGDGT distributions towards those seen in soils must be due to their production within sediments.

The BIT index of IPL brGDGTs in the short sediment profile is consistently higher than that of CL brGDGTs (Fig. 6C); to a lesser extent this is also the case in surface sediments. Since crenarchaeol is likely not produced within these anoxic sediments, this could be explained by brGDGTs being produced within the sediments. The alternative explanation that IPLs of crenarchaeol are preferentially degraded compared with potentially more resilient IPL brGDGTs contrasts with suggestions that brGDGTs predominantly contain phosphatic rather than glycosidic head groups (Peterse et al., 2011; Weijers et al., 2011), although it must be emphasized that the latter referred to evidence from soils and peat. Eventually, since ambient temperatures are likely to be constant in the top $13.5 \mathrm{~cm}$ of sediment, confirmation of in-situ production is difficult to prove using only MBT and CBT values. Even if in-situ production were occurring, fluctuations in brGDGT distribution downcore may simply be due to variations in water column conditions above otherwise stable sediment conditions.

In conclusion, this diverse dataset provides indirect evidence that, in-situ brGDGT production most likely occurs within Lake Challa sediments. Given the similarity of this organic-carbon rich, anoxic sediment with the water-saturated catotelm of peat bogs where brGDGT-producing bacteria demonstrably proliferate (Weijers et al., 2006a), this is perhaps unsurprising. High \%IPLs in the sediments, the offset between MBT and CBT values from settling particles and sediments, and the downcore BIT index of IPL brGDGTs being consistently higher than that of CL brGDGTs all point in this direction. However, the exact relative proportions of water column and sedimentary production are impossible to resolve based on our data. Unfortunately this means that it is probably not possible to ascertain the effect of sedimentary production on brGDGT distributions in lake sediment archives.

\subsection{Implications for brGDGT-based palaeothermometry in lakes}

The Peterse et al. (2012) soil calibration for MBT'/CBT yields mean MAAT estimates (Table 3) in Lake Challa surface sediments of $7.5^{\circ} \mathrm{C} \pm 1.8$ (CL) and $6.9 \pm 1.6{ }^{\circ} \mathrm{C}$ (IPL), which are clearly much lower than the locally measured MAAT of $23{ }^{\circ} \mathrm{C}$ and also lower than any MAAT estimates based on local soils (Table S1). Low MBT/CBT-based MAAT estimates and a mismatch in brGDGT distribution between soils and lake sediments have been noted in previous studies (Tierney and Russell, 2009; Blaga et al., 2010; Tierney et al., 2010), supporting the notion of brGDGT production within lakes. The original Tierney et al. (2010) and expanded Loomis et al. (2012) brGDGT calibrations for East African lakes applied to the mean CL brGDGT distributions of Lake Challa surface sediments produce MAAT estimates of respectively $19.2 \pm 2.0{ }^{\circ} \mathrm{C}$ and $16.7 \pm 1.9{ }^{\circ} \mathrm{C}$ (Table 3 ), still lower than the actual MAAT of $23.0{ }^{\circ} \mathrm{C}$. While these estimates have comparable standard deviations, they fall outside of the calibrations' root mean squared errors (RMSEs) of \pm 2.2 (Tierney et al., 2010) and $1.9{ }^{\circ} \mathrm{C}$ (Loomis et al., 2012). MAAT estimates using the expanded Loomis-2012 calibration are on average $2.5{ }^{\circ} \mathrm{C}$ lower (and further from measured MAAT) than those generated by the original Tierney-2010 calibration. Loomis et al. (2012) augmented that 46-lake dataset predominantly with sites in the Rwenzori mountains and on Mt. Kenya, specifically targeting cold lakes with high $\mathrm{pH}$. One advantage of the Tierney-2010 calibration is the wide range of altitudes (and therefore MAATs) covered within a relatively small area of equatorial East Africa. Since Lake Challa is a warm low-elevation site in south-eastern Kenya, we deem it more 
appropriate to apply the Tierney-2010 calibration here. All further lake MAAT estimates for Lake Challa will be derived from this calibration (equation 8).

The Tierney-2010 lake calibration produces not only low mean MAAT estimates from brGDGTs in bottom surface sediments (Table 3, Fig. 7A) but even lower estimates from mean abundance-weighted CL brGDGTs in SPM throughout the water column $\left(15.4 \pm 5.8{ }^{\circ} \mathrm{C}\right.$; Fig. 7B) and in settling particles at $35 \mathrm{~m}$ depth $\left(14.4 \pm 5.3{ }^{\circ} \mathrm{C}\right.$, Fig. $\left.7 \mathrm{C}\right)$. One possible explanation for this offset may be that Lake Challa has a more confined catchment and consequently higher ratio of autochthonous brGDGTs (produced within the lake) versus allochthonous brGDGTs (derived from surrounding soils) than other lakes in the Tierney-2010 calibration. In fact, however, most low-elevation lakes in the Tierney-2010 calibration are either crater lakes as well, or large lakes where a considerable contribution from autochthonous brGDGTs may be expected. The offset between estimated and measured MAAT using the Tierney-2010 calibration may nevertheless point to a sensitivity of individual lakes to changes in the relative contributions of autochthonous and allochthonous brGDGTs to the sediments. An additional complicating factor may be different relative contributions of water column and sedimentary brGDGT production to the autochthonous brGDGT pool. The contributions of these respective pools may also change over time, requiring careful consideration of past changes in lake hydrology that may have affected these contributions.

Further, our 33-month time series of brGDGTs in settling particles produces marked seasonal oscillation in monthly MAAT estimates, which range between 7 and $25{ }^{\circ} \mathrm{C}$ with distinct minima occurring approximately annually in January 2008, December 2008 and February 2010 (Fig. 2I); MAAT estimates based on IPL and CL brGDGTs are generally similar. Needless to emphasise, this amplitude of seasonal oscillation is much greater than measured locally either in the air or in the water column (Figs. 2A-B). Notably, estimated temperature maxima and minima show a systematic offset of 5-6 months from measured local air temperature, and ca. 3 months from measured water column temperatures. The highamplitude seasonal cycle in estimated MAAT may result from admixture, during partial lake turnover, with 'fossil' brGDGTs from a pool suspended and preserved in the lower water column. However, since temperature estimates inferred from brGDGT distributions in the occasionally mixed anoxic part of the water column (45-60 m depth; 10.9-12.5 $\left.{ }^{\circ} \mathrm{C}\right)$ are still well above the lowest values observed in the time series of particles settling at $35 \mathrm{~m}$, largescale admixture of this 'fossil' pool seems unlikely.

The substantial mismatch between MAAT inferred from the time series of settling particles and actual water column temperatures suggests that the distributions of in-situ produced brGDGTs may have a different relationship to temperature than accounted for in the East African lake surface-sediment calibrations. This could be due to the mixed origin of surface-sediment brGDGTs, potentially having been contributed by distinct bacterial communities in soils, the water column and sediments. It is also possible that variables other than temperature are involved in determining brGDGT distributions in settling particles. Seasonal events in lakes such as changes in temperature and water column stratification are typically associated with changes in bacterial community composition (Shade et al., 2007). In Lake Challa, the deep mixing that occurs annually between June and September (Fig. 2A) reaches to between 45 and $60 \mathrm{~m}$ (Sinninghe Damsté et al., 2009); nutrients brought from these depths to the oxygenated surface waters support the annual diatom bloom (Wolff et al., 2011; Barker et al., 2013). Since temperatures inferred from brGDGTs in settling particles (Fig. 2I) begin to drop during this deep mixing season, we surmise that either brGDGT-producing bacteria are adapting to new conditions, or are undergoing a community change. 
To assess whether the seasonal cycle of inferred MAAT (Fig. 2I) is driven by variation in lakewater temperature, we plotted MAAT estimates from settling particles against the corresponding mean monthly water temperatures at $20 \mathrm{~m}$ depth (the most appropriate in-situ temperature available on this timescale, Fig. 2A). These data (Fig. 7C) display extensive scatter below the 1:1 line, also evident when MAAT estimates from SPM are plotted against water temperature measured at the sampled depths (Fig. 7B). This confirms that the East African lake brGDGT calibration (Tierney et al., 2010) does not reconstruct lake water temperature accurately, at least not in Lake Challa.

In an attempt to further resolve the relationships between ambient water column conditions and the distributions of in-situ produced brGDGTs, we analysed the correlations between MBT and CBT values derived from IPL and CL brGDGTs in the SPM profile from February 2010 with local water temperature measured at that time (Table 4). Given the logarithmic nature of the CBT ratio, we replaced it with the (linear) degree of cyclisation (DC, equation 4) to assess correlation with the linear variable temperature. The most striking result of this analysis is that SPM MBT and DC both correlate strongly and positively with the depth gradient of local water temperature $\left(r^{2}=0.82\right.$ and 0.59 , respectively, for IPL; $r^{2}=0.91$ and 0.80 for CL brGDGTs). After removal of data points from below $45 \mathrm{~m}$, where conditions are generally static and brGDGTs have a much longer residence time, the correlations are even higher $\left(r^{2}=0.91\right.$ and 0.81 for IPL; 0.96 and 0.91 for CL; Table 4 and Fig. 8A). This strong relationship confirms that brGDGT-producing bacteria in the water column adjust their membrane lipids to local differences (and perhaps also temporal changes; cf. below) in temperature.

Given these highly significant correlations with temperature, we plotted SPM MBT and DC together with temperature (all limited to values from above $45 \mathrm{~m}$ ) in a 3D correlation to test whether this combination could predict temperature even better. Both the sampled SPM and depth-related temperature gradient represent a snapshot in time of the Lake Challa water column, and hence cover a relatively small temperature range. Therefore, they should be interpreted with caution. Nevertheless, highly significant relationships between these three variables emerge $\left(\mathrm{r}^{2}=0.91\right.$ for IPL; 0.97 for CL; shown for CL in Fig. 8B). For the CL brGDGTs this 3D calibration is an improvement over the 2D MBT-temperature calibration. For the IPL brGDGTs, inclusion of DC does not improve the correlation and hence the 2D MBT-temperature calibration (Fig. 8A) can be used instead.

Acknowledging the uncertainties associated with this 'local' (or 'in-lake') calibration of brGDGT distributions in our SPM dataset, application of the CL (3D) and IPL (2D) 'local SPM' calibrations to brGDGTs in the settling particles and surface sediments from Lake Challa can improve our understanding of the relationship between brGDGT distributions in both settings, as well as of the signature of seasonal variation in water column temperatures. Application of the CL and IPL 'local SPM' calibrations to settling particles generates fluxweighted mean temperatures of $24.3^{\circ} \mathrm{C}$ and $24.5{ }^{\circ} \mathrm{C}$, respectively, over two years of measurement (Table 3 ). Comparing these estimates with measured water column temperatures is difficult because the precise depth that best represents the mean flux of brGDGTs to the sediment trap at $35 \mathrm{~m}$ is unknown. Based on the relative concentration of brGDGTs in SPM collected between 0 and $30 \mathrm{~m}$ depth, we consider the mean monthly temperature at $20 \mathrm{~m}$ to be a best estimate for the purpose of comparison. Integrated over two full years (from $1 / 2 / 2008$ to $31 / 1 / 2010$ ) this measured value is $24.4{ }^{\circ} \mathrm{C}$, identical to the inferred values. This confirms that the estimates are accurate, and that our 'local SPM' calibrations are a reasonable approximation of the temperature dependence of brGDGT distribution in the water column. However, although the mean annual temperature inference for settling particles seems 
accurate, when applied to the actual time series of brGDGT distributions in settling particles, it does not accurately infer water temperature over the relevant depth interval on either a monthly or seasonal basis (Fig. 2J). As discussed above, this is most probably due to the heterogeneous origin of brGDGT assemblages in the water column throughout the year.

When applied to the mean brGDGT distribution in surface sediments, the CL and IPL 'local SPM' calibrations yield temperature estimates of 26.0 and $25.8{ }^{\circ} \mathrm{C}$ (Table 3), higher than the measured mean annual water temperature in the upper water column. This begs the question: why is the temperature inference from surface sediment brGDGT distributions biased towards higher values? Since neither the temperature range nor strength of the MBT and DC correlations change substantially when based on the full SPM depth profile from 0.5 to $89.4 \mathrm{~m}$ depth, high temperature estimates are not likely due to differently distributed brGDGTs exported to the bottom sediment from lower in the water column; in fact, this would result in a lower (not higher) temperature estimate. The notable difference between temperature inferred from settling particles and surface sediments thus also argues for an additional source of brGDGTs within the sediments.

CBT values derived from both IPL and CL brGDGTs in SPM correlate relatively weakly $\left(\mathrm{r}^{2}=0.60\right.$ and 0.54 , respectively) with local $\mathrm{pH}$ in the water column (Table 4$)$; in fact, the corresponding MBT values have similar correlation coefficients with $\mathrm{pH}\left(\mathrm{r}^{2}=0.59\right.$ and 0.50 , respectively). Additionally, DC and CBT ratios from SPM correlate more strongly with measured temperature than with $\mathrm{pH}$. This is in line with the results of Tierney et al. (2010), who also noted that $\mathrm{pH}$ control on brGDGT distributions across 46 lakes in their East African dataset is secondary to that of temperature. These correlations signify that brGDGT-producing bacterial communities in the water column are likely different to those found in soils, and that lake-water pH cannot be inferred accurately using solely the CBT, as is done in soils (e.g. Weijers et al., 2007a; Peterse et al., 2009). To assess whether a combination of MBT and CBT might allow $\mathrm{pH}$ inference, we plotted MBT and CBT values from SPM above $45 \mathrm{~m}$ depth against local $\mathrm{pH}$, revealing a strong correlation for both $\mathrm{CL}\left(\mathrm{r}^{2}=0.98\right.$, Fig. $\left.8 \mathrm{C}\right)$ and IPL brGDGTs $\left(r^{2}=0.97\right.$, Fig. 8D). Thus, since MBT and CBT seem both affected by local differences in water column $\mathrm{pH}$, they could theoretically be used in tandem to reconstruct past lakewater $\mathrm{pH}$ when a large proportion of sedimentary brGDGTs are produced in the water column.

\section{CONCLUSIONS}

Based on comparisons of CL and IPL brGDGT distributions in catchment soils, material settling over time in a sediment trap, suspended particulate matter and surface sediments, we conclude that brGDGT-producing bacteria live in the water column of Lake Challa, in addition to inhabiting the surrounding soils. This means that the sediments contain a mixture of soil- and lake-derived brGDGTs, with the autochthonous component appearing to be considerably larger than the allochthonous, soil-derived component at least in this lake. BrGDGT production occurs throughout the water column, although the majority of brGDGTs found in sediments are exported from the suboxic zone below the principal thermocline. Additional brGDGT production within the lake bottom (surface) sediments in addition to that in the water column is likely, but determining the precise proportions of sediment-derived and water column-derived brGDGTs is not possible due to their similar distributions. BrGDGTs produced in the water column of Lake Challa have an inherently different relationship to ambient temperature to those produced in soils, affecting sediment-derived MBT/CBT temperature estimates. Ambient water temperature and $\mathrm{pH}$ appear to directly affect brGDGT 
distributions within the water column; using these relationships, relatively accurate water temperature estimates can be generated from settling particles but fail for surface sediments.

ACKNOWLEDGEMENTS. We would like to thank all those who provided fieldwork support, notably C. Mukhwana Oluseno, and further D. van de Meent, A. van Leeuwen, A. van Dijk and J. Ossebaar for analytical assistance. We thank the Kenyan Ministry of Agriculture for monthly precipitation data from the Challa Agricultural Station, and A. Hemp for air temperature data. We would like to acknowledge the editor and three anonymous reviewers for providing valuable comments and suggestions that helped us to improve this manuscript. The research leading to the results presented here received funding from the European Research Council under the European Union's Seventh Framework Programme (FP7/2007-2013) / ERC grant agreement $n^{\circ}$ 226600. J.W.H.W. acknowledges support from a Veni grant from the Netherlands Organisation for Scientific Research (NWO). Fieldwork was conducted with support from the Research Foundation Flanders (FWO) and under permit 13/001/11C of the Kenyan Ministry of Education, Science and Technology to D.V.

\section{REFERENCES}

Barker P. A., Hurrell E. R., Leng M. J., Plessen B., Wolff C., Conley D. J., Keppens E., Milne I., Cumming B. F., Laird K. R., Kendrick C. P., Wynn P. M. and Verschuren D. (2013) Carbon cycling within an East African lake revealed by the carbon isotope composition of diatom silica: a 25-ka record from Lake Challa, Mt. Kilimanjaro. Quat. Sci. Rev. 66, 55-63.

Barker, P.A., Hurrell, E.R., Leng, M.J., Wolff, C, Cocquyt, C., Sloane, H.J. \& Verschuren, D. (2011). Seasonality in equatorial climate over the last 25,000 years revealed by oxygen isotope records from Mount Kilimanjaro. Geology 39, 1111-1114.

Bauersachs T., Speelman E. N., Hopmans E. C., Reichart G., Schouten S. and Sinninghe Damsté J. S. (2010) Fossilized glycolipids reveal past oceanic $\mathrm{N}_{2}$ fixation by heterocystous cyanobacteria. Proc. Nat. Acad. Sci. USA 107, 19190-19194.

Bechtel A., Smittenberg R. H., Bernasconi S. M. and Schubert C. J. (2010) Distribution of branched and isoprenoid tetraether lipids in an oligotrophic and a eutrophic Swiss lake: Insights into sources and GDGT-based proxies. Org. Geochem. 41, 822-832.

Bendle J.A., Weijers, J.W.H., Maslin M.A., Sinninghe Damsté J.S., Schouten S., Hopmans E.C., Boot C.S. and Pancost R.D. (2010) Major changes in the glacial and Holocene terrestrial temperatures and sources of organic carbon recorded in the Amazon fan by tetraether lipids. Geochem. Geophys. Geosyst. 11, 1-13.

Blaga C. I., Reichart G. J., Heiri O. and Sinninghe Damsté J. S. (2009) Tetraether membrane lipid distributions in water column particulate matter and sediments: a study of 47 European lakes along a north-south transect. J. Paleolimnol. 41, 523-540.

Blaga C. I., Reichart G., Schouten S., Lotter A. F., Werne J. P., Kosten S., Mazzeo N., Lacerot G. and Sinninghe Damsté J. S. (2010) Branched glycerol dialkyl glycerol tetraethers in lake sediments: Can they be used as temperature and $\mathrm{pH}$ proxies? Org. Geochem. 41, 1225-1234.

Bligh E. G. and Dyer W. J. (1959) A rapid method of total lipid extraction and purification. Can. J. Biochem. Physiol. 37, 911-917.

Buckles L.K., Villanueva L., Weijers J.W.H., Verschuren D., Sinninghe Damsté J.S. (2013) Linking isoprenoidal GDGT membrane-lipid distributions with gene abundances of 
ammonia-oxidising Thaumarchaeota and uncultured crenarchaeotal groups in the water column of a tropical lake (Lake Challa, East Africa). Environ. Microbiol. 15, 2445-2462.

Dirghangi S. S., Pagani M., Hren M. T. and Tipple B. J. (2013) Distribution of glycerol dialkyl glycerol tetraethers in soils from two environmental transects in the USA. Org. Geochem. 59, 49-60.

Donders T.H., Weijers J.W.H., Munsterman D.K., Kloosterboer-van Hoeve M.L., Buckles L.K., Pancost R.D., Schouten S., Sinninghe Damsté J.S. and Brinkhuis H. (2009) Strong climate coupling of terrestrial and marine environments in the Miocene of northwest Europe. Earth Planet. Sci. Lett. 281, 215-225.

Harvey H. R., Fallon R. D. and Patton J. S. (1986) The effect of organic matter and oxygen on the degradation of bacterial membrane lipids in marine sediments. Geochim. Cosmochim. Acta 50, 795-804.

Hemp A. (2006) Continuum or zonation? Altitudinal gradients in the forest vegetation of Mt. Kilimanjaro. Plant Ecol. 184, 27-42.

Hopmans E. C., Weijers J. W. H., Schefu $\beta$ E., Herfort L., Sinninghe Damsté J. S. and Schouten S. (2004) A novel proxy for terrestrial organic matter in sediments based on branched and isoprenoid tetraether lipids. Earth Planet. Sci. Lett. 224, 107-116.

Huguet C., Hopmans E. C., Febo-Ayala W., Thompson D. H., Sinninghe Damsté J. S. and Schouten S. (2006) An improved method to determine the absolute abundance of glycerol dibiphytanyl glycerol tetraether lipids. Org. Geochem. 37, 1036-1041.

Keating-Bitonti C.R., Ivany L.C., Affek H.P., Douglas P. and Samson S.D. (2011) Warm, not super-hot, temperatures in the early Eocene subtropics. Geology 39, 771-774.

Kristen, I. (2009) Investigations on rainfall variability during the late Quarternary based on geochemical analyses of lake sediments from tropical and subtropical southern Africa. $\mathrm{PhD}$ thesis, Universität Potsdam.

Lengger S. K., Hopmans E. C., Reichart G., Nierop K. G. J., Sinninghe Damsté J. S. and Schouten S. (2012) Intact polar and core glycerol dibiphytanyl glycerol tetraether lipids in the Arabian Sea oxygen minimum zone. Part II: Selective preservation and degradation in sediments and consequences for the $\mathrm{TEX}_{86}$. Geochim. Cosmochim. Acta 98, 244-258.

Loomis S. E., Russell J. M. and Sinninghe Damsté J. S. (2011) Distributions of branched GDGTs in soils and lake sediments from western Uganda: Implications for a lacustrine paleothermometer. Org. Geochem. 42, 739-751.

Loomis S. E., Russell J. M., Ladd B., Street-Perrott F. A. and Sinninghe Damsté J. S. (2012) Calibration and application of the branched GDGT temperature proxy on East African lake sediments. Earth Planet. Sci. Lett. 357-358, 277-288.

McCave I. N. (1984) Size spectra and aggregation of suspended particles in the deep ocean. Deep Sea Res. 31, 329-352.

Moernaut J., Verschuren D., Charlet F., Kristen I., Fagot M., De Bastist M. (2010) The seismic-stratigraphic record of lake-level fluctuations in Lake Challa: Hydrological stability and change in equatorial East Africa over the last 140 kyr. Earth Planet. Sci. Lett., 209, 214-223.

Niemann H., Stadnitskaia A., Wirth S.B., Gilli A., Anselmetti F.S., Sinninghe Damsté J.S., Schouten S., Hopmans E.C. and Lehmann M.F. (2012) Bacterial GDGTs in Holocene sediments and catchment soils of a high Alpine lake: Application of the MBT/CBTpaleothermometer. Clim. Past 8, 889-906.

Payne B. R. (1970) Water balance of Lake Chala and its relation to groundwater from tritium and stable isotope data. J. Hydrol. 11, 47-58. 
Pearson E. J., Juggins S., Talbot H. M., Weckström J., Rosén P., Ryves D. B., Roberts S. J. and Schmidt R. (2011) A lacustrine GDGT-temperature calibration from the Scandinavian Arctic to Antarctic: Renewed potential for the application of GDGTpaleothermometry in lakes. Geochim. Cosmochim. Acta 75, 6225-6238.

Peterse F., Schouten S., van der Meer J., van der Meer M. T .J. and Sinninghe Damsté J. S. (2009) Distribution of branched tetraether lipids in geothermally heated soils: Implications for the MBT/CBT temperature proxy. Org. Geochem. 40, 201-205.

Peterse F., Nicol G. W., Schouten S. and Sinninghe Damsté J. S. (2010) Influence of soil pH on the abundance and distribution of core and intact polar lipid-derived branched GDGTs in soil. Org. Geochem. 41, 1171-1175.

Peterse F., Hopmans E. C., Schouten S., Mets A., Rijpstra W. I. C. and Sinninghe Damsté J. S. (2011) Identification and distribution of intact polar branched tetraether lipids in peat and soil. Org. Geochem. 42, 1007-1015.

Peterse F., van der Meer J., Schouten S., Weijers J. W. H., Fierer N., Jackson R. B., Kim J. and Sinninghe Damsté J. S. (2012) Revised calibration of the MBT-CBT paleotemperature proxy based on branched tetraether membrane lipids in surface soils. Geochim. Cosmochim. Acta 96, 215-229.

Pitcher A., Hopmans E. C., Schouten S. and Sinninghe Damsté J. S. (2009) Separation of core and intact polar archaeal tetraether lipids using silica columns: Insights into living and fossil biomass contributions. Org. Geochem. 40, 12-19.

Pitcher A., Wuchter C., Siedenberg K., Schouten S. and Sinninghe Damsté J. S. (2011) Crenarchaeol tracks winter blooms of ammonia-oxidizing Thaumarchaeota in the coastal North Sea. Limnol. Oceangr. 56, 2308-2318.

Pross J., Contreras, L., Bijl P.K., Greenwood D.R., Bohaty S.M., Schouten S., Bendle J.A., Röhl U., Tauxe L., Raine J.I., Huck C.E., van de Flierdt T., Jamieson S.S.R., Stickley C.E., van de Schootbrugge B., Escutia C., Brinkhuis H. and Integrated Ocean Drilling Program Expedition 318 Scientists (2012) Persistent near-tropical warmth on the Antarctic continent during the early Eocene epoch. Nature 488, 73-77.

Schouten S., Wakeham S. G. and Sinninghe Damsté J. S. (2001) Evidence for anaerobic methane oxidation by archaea in euxinic waters of the Black Sea. Org. Geochem. 32, $1277-1281$.

Schouten S., Huguet C., Hopmans E. C., Kienhuis M. V. M. and Sinninghe Damsté J. S. (2007) Analytical methodology for $\mathrm{TEX}_{86}$ paleothermometry by high-performance liquid chromatography/atmospheric pressure chemical ionization-mass spectrometry. Anal. Chem. 79, 2940-2944.

Schouten S., Eldrett J., Greenwood D. R., Harding I., Baas M. and Sinninghe Damsté J. S. (2008) Onset of long-term cooling of Greenland near the Eocene-Oligocene boundary as revealed by branched tetraether lipids. Geology 36, 147-150.

Schouten S., Middelburg J. J., Hopmans E. C. and Sinninghe Damsté J. S. (2010) Fossilization and degradation of intact polar lipids in deep subsurface sediments: A theoretical approach. Geochim. Cosmochim. Acta 74, 3806-3814.

Schouten S., Rijpstra W. I. C., Durisch-Kaiser E., Schubert C. J. and Sinninghe Damsté J. S. (2012) Distribution of glycerol dialkyl glycerol tetraether lipids in the water column of Lake Tanganyika. Org. Geochem. 53, 34-37.

Schouten S., Hopmans E. C. and Sinninghe Damsté J. S. (2013) The organic geochemistry of glycerol dialkyl glycerol tetraether lipids: A review. Org. Geochem. 54, $19-61$.

Shade A., Kent A. D., Jones S. E., Newton R. J., Triplett E. W. and McMahon K. D. (2007) Interannual Dynamics and Phenology of Bacterial Communities in a Eutrophic Lake. Limnol. Oceanogr. 52, 487-494. 
Shanahan T.M., Hughen K.A. and Van Mooy B.A.S. (2013) Temperature sensitivity of branched and isoprenoid GDGTs in Arctic lakes. Org. Geochem. 64, 119-128.

Sinninghe Damsté J. S., Hopmans E. C., Pancost R. D., Schouten S. and Geenevasen J. A. J. (2000) Newly discovered non-isoprenoid glycerol dialkyl glycerol tetraether lipids in sediments. Chem. Commun. 17, 1683-1684.

Sinninghe Damsté J. S., Ossebaar J., Schouten S. and Verschuren D. (2008) Altitudinal shifts in the branched tetraether lipid distribution in soil from Mt. Kilimanjaro (Tanzania): Implications for the MBT/CBT continental palaeothermometer. Org. Geochem. 39, 10721076.

Sinninghe Damsté J. S., Ossebaar J., Abbas B., Schouten S. and Verschuren D. (2009) Fluxes and distribution of tetraether lipids in an equatorial African lake: Constraints on the application of the $\mathrm{TEX}_{86}$ palaeothermometer and BIT index in lacustrine settings. Geochim. Cosmochim. Acta 73, 4232-4249.

Sinninghe Damsté J. S., Rijpstra W. I. C., Hopmans E. C., Weijers J. W. H., Foesel B. U., Overmann J. and Dedysh S. N. (2011) 13,16-Dimethyl octacosanedioic acid (iso-diabolic acid): A common membrane-spanning lipid of Acidobacteria subdivisions 1 and 3. Appl. Environ. Microbiol. 77, 4147-4154.

Sinninghe Damsté J. S., Ossebaar J., Schouten S. and Verschuren D. (2012) Distribution of tetraether lipids in the 25-ka sedimentary record of Lake Challa: Extracting reliable $\mathrm{TEX}_{86}$ and MBT/CBT palaeotemperatures from an equatorial African lake. Quat. Sci. Rev. 50, 43-54.

Sun Q., Chu G., Liu M., Xie M., Li S., Ling Y., Wang X., Shi L., Jia G. and Lü H. (2011) Distributions and temperature dependence of branched glycerol dialkyl glycerol tetraethers in recent lacustrine sediments from China and Nepal. J. Geophys. Res. 116, G01008.

Tierney J. E. and Russell J. M. (2009) Distributions of branched GDGTs in a tropical lake system: Implications for lacustrine application of the MBT/CBT paleoproxy. Org. Geochem. 40, 1032-1036.

Tierney J. E., Russell J. M., Eggermont H., Hopmans E. C., Verschuren D. and Sinninghe Damsté J. S. (2010) Environmental controls on branched tetraether lipid distributions in tropical East African lake sediments. Geochim. Cosmochim. Acta 74, 4902-4918.

Tierney J. E., Schouten S., Pitcher A., Hopmans E. C. and Sinninghe Damsté J. S. (2012) Core and intact polar glycerol dialkyl glycerol tetraethers (GDGTs) in Sand Pond, Warwick, Rhode Island (USA): Insights into the origin of lacustrine GDGTs. Geochim. Cosmochim. Acta 77, 561-581.

Tyler J. J., Nederbragt A.J., Jones V.J. and Thurrow J.W. (2010) Assessing past temperature and soil $\mathrm{pH}$ estimates from bacterial tetraether membrane lipids: Evidence from the recent lake sediments of Lochnagar, Scotland. J. Geophys. Res. 115, G01015.

Verschuren D., Sinninghe Damsté J. S., Moernaut J., Kristen I., Blaauw M., Fagot M., Haug G. H. and Challacea project members (2009) Half-precessional dynamics of monsoon rainfall near the East African Equator. Nature 462, 637-641.

Wakeham S. G., Lewis C. M., Hopmans E. C., Schouten S. and Sinninghe Damsté J. S. (2003) Archaea mediate anaerobic oxidation of methane in deep euxinic waters of the Black Sea. Geochim. Cosmochim. Acta 67, 1359-1374.

Weijers J. W. H., Schouten S., Hopmans E. C., Geenevasen J. A. J., David O. R. P., Coleman J. M., Pancost R. D. and Sinninghe Damsté J. S. (2006a) Membrane lipids of mesophilic anaerobic bacteria thriving in peats have typical archaeal traits. Environ. Microbiol. 8, 648-657. 
Weijers J. W. H., Schouten S., Spaargaren O. C. and Sinninghe Damsté J. S. (2006b) Occurrence and distribution of tetraether membrane lipids in soils: Implications for the use of the TEX T6 $_{86}$ proxy and the BIT index. Org. Geochem. 37, 1680-1693.

Weijers J. W. H., Schouten S., van den Donker J. C., Hopmans E. C. and Sinninghe Damsté J. S. (2007a) Environmental controls on bacterial tetraether membrane lipid distribution in soils. Geochim. Cosmochim. Acta 71, 703-713.

Weijers J. W. H., Schefuss E., Schouten S. and Sinninghe Damsté J. S. (2007b) Coupled thermal and hydrological evolution of tropical Africa over the last deglaciation. Science 315, 1701-1704.

Weijers J. W. H., Schouten S., Sluijs A., Brinkhuis H. and Sinninghe Damsté J. S. (2007c) Warm Arctic continents during the Palaeocene-Eocene thermal maximum. Earth Planet. Sci. Lett. 261, 230-238.

Weijers J. W. H., Panoto E., van Bleijswijk J., Schouten S., Rijpstra W. I. C., Balk M., Stams A. J. M. and Sinninghe Damsté J. S. (2009) Constraints on the biological source(s) of the orphan branched tetraether membrane lipids. Geomicrobiol. J. 26, 402-414.

Weijers J. W. H., Wiesenberg G. L. B., Bol R., Hopmans E. C. and Pancost R. D. (2010) Carbon isotopic composition of branched tetraether membrane lipids in soils suggest a rapid turnover and a heterotrophic life style of their source organism(s). Biogeosciences 7, 2959-2973.

Weijers J. W. H., Bernhardt B., Peterse F., Werne J. P., Dungait J. A. J., Schouten S. and Sinninghe Damsté J. S. (2011) Absence of seasonal patterns in MBT-CBT indices in mid-latitude soils. Geochim. Cosmochim. Acta 75, 3179-3190.

Wolff C., Haug G. H., Timmermann A., Sinninghe Damsté J. S., Brauer A., Sigman D. M., Cane M. A. and Verschuren D. (2011) Reduced interannual rainfall variability in East Africa during the last Ice Age. Science 333, 743-747.

Wuchter C., Schouten S., Wakeham S. G. and Sinninghe Damsté J. S. (2005) Temporal and spatial variation in tetraether membrane lipids of marine Crenarchaeota in particulate organic matter: Implications for $\mathrm{TEX}_{86}$ paleothermometry. Paleoceanography 20, PA3013.

Yang H., Pancost R.D., Dang X., Zhou X., Evershed R.P., Xiao G., Tang C., Gao L., Guo Z. and Xie S. (2014) Correlations between microbial tetraether lipids and environmental variables in Chinese soils: Optimizing the paleo-reconstructions in semi-arid and arid regions. Geochim. Cosmochim. Acta 126, 49-69.

Zink K., Vandergoes M. J., Mangelsdorf K., Dieffenbacher-Krall A. C. and Schwark L. (2010) Application of bacterial glycerol dialkyl glycerol tetraethers (GDGTs) to develop modern and past temperature estimates from New Zealand lakes. Org. Geochem. 41, 1060-1066. 


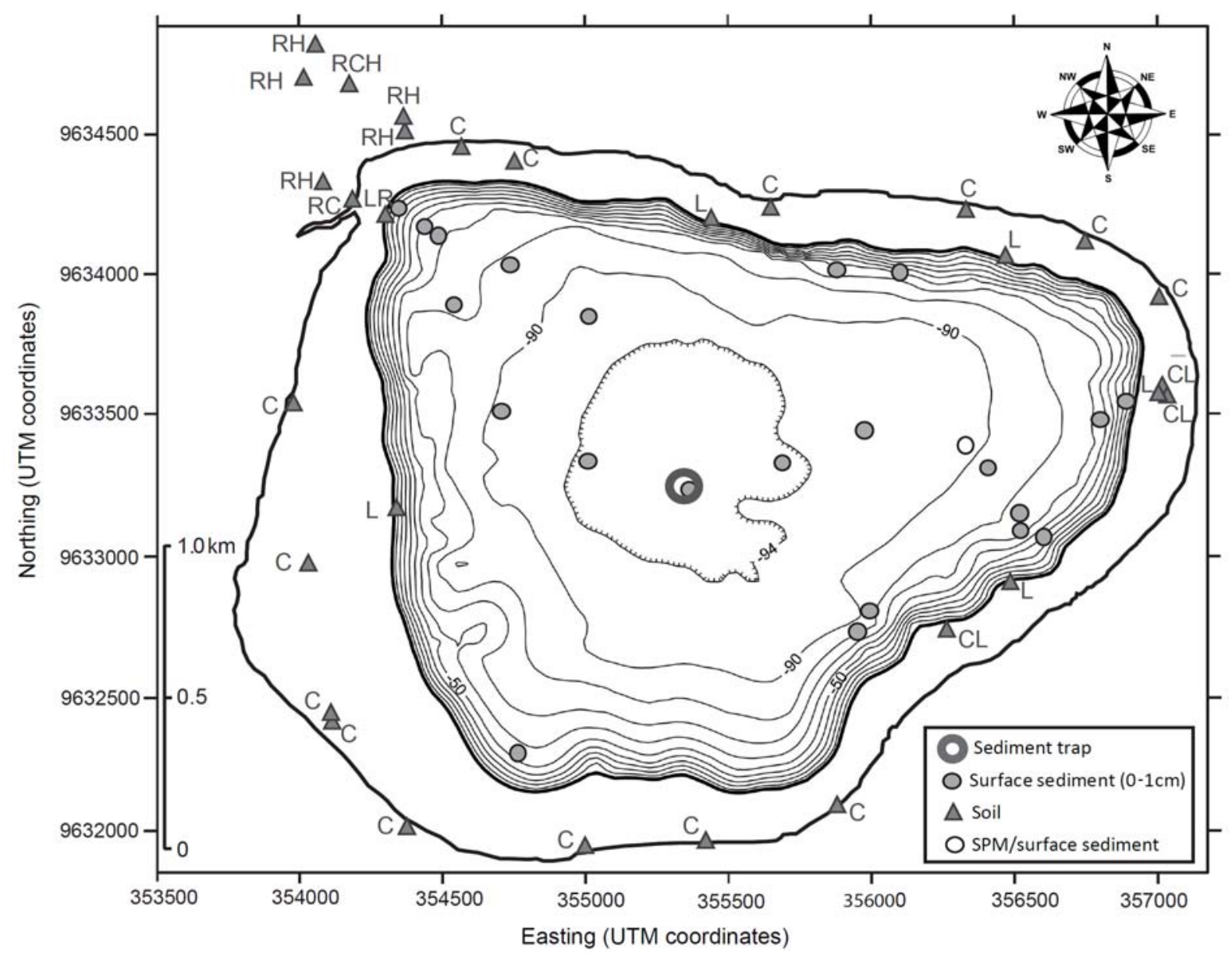

Figure 1: Lake Challa bathymetry (courtesy of J. Moernaut, Ghent University) and sampling locations of terrestrial soils in the vicinity of the lake and its catchment, suspended particulate matter (SPM), settling particles (in a centrally located sediment trap) and bottom surface sediments. Scale is in the Universal Transverse Mercator (UTM) global coordinate system. The outermost bold black line signifies the catchment boundary. Soil samples are labelled according to their distinct (sometimes shared) site origins, with $\mathrm{R}=$ ravine, $\mathrm{C}=\mathrm{crater}$ slope/rim, $\mathrm{L}=$ lakeshore and $\mathrm{H}=$ hinterland. 


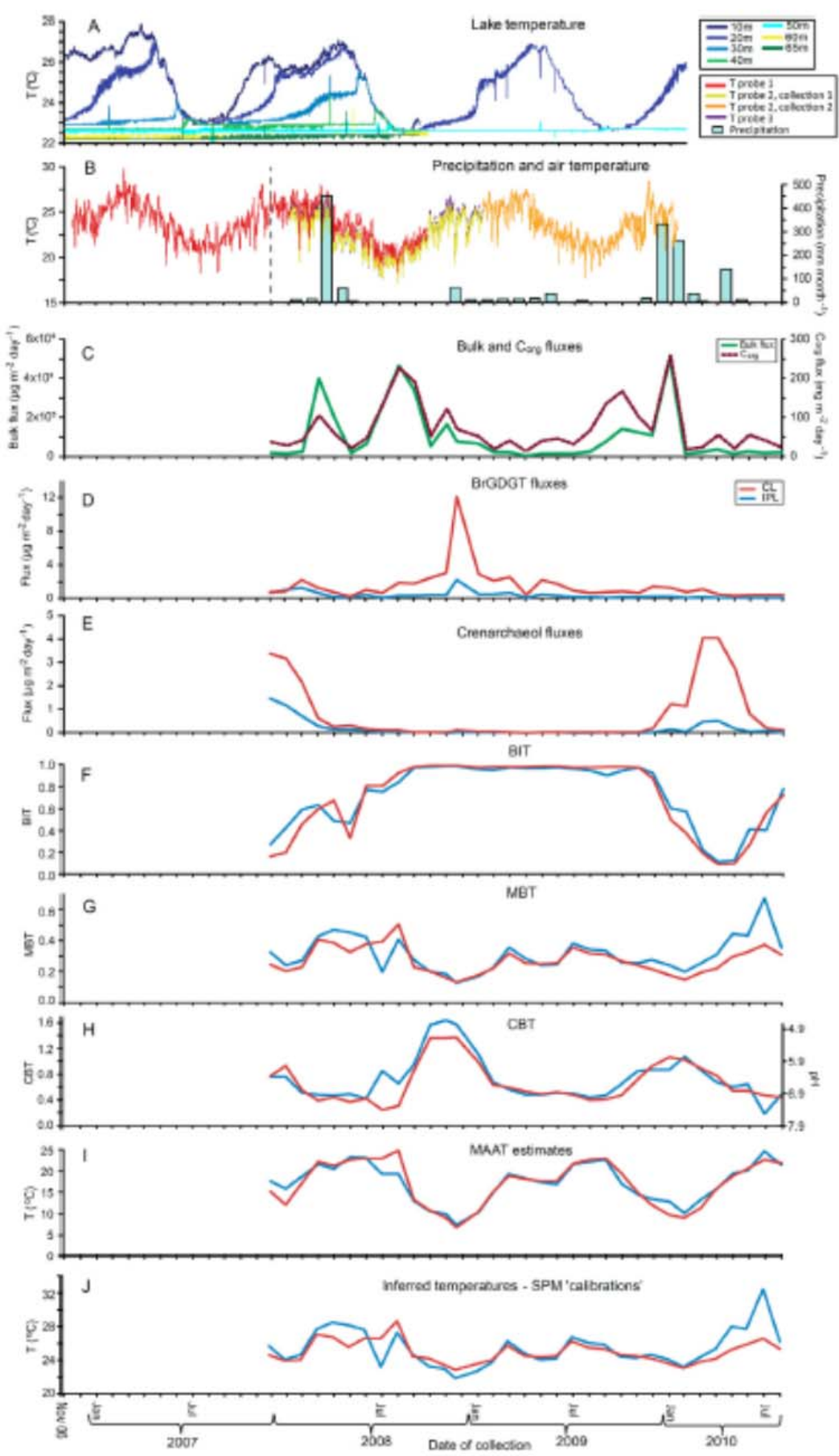

Figure 2: Time series data for Lake Challa. (A) Lake water and (B) air temperature recorded between November 2006 and January 2010. Water temperatures were measured at different depths in the water column using Vemco thermistors mounted on the mooring of the sediment trap. Air temperature was measured by three Tidbit loggers situated at various locations on the lake side of the crater rim around Lake Challa; data from probes 2 and 3 are courtesy of Dr. A. Hemp (University of Bayreuth). Also given in (B) is the monthly precipitation at a Kenya government agricultural station immediately north of Lake Challa over the period December 2007 - August 2010. Time series data of settling particles during this period consist of fluxes of (C) bulk sedimenting particles and their total organic carbon $\left(\mathrm{C}_{\text {org }}\right.$ ) content, (D) IPL and CL brGDGTs and (E) IPL and CL crenarchaeol (note different scales on y-axis in C-E); variations in (F) BIT index, $(\mathrm{G})$ MBT index, (H) CBT ratio, (I) MBT/CBTderived MAAT estimates using the East African lake calibration of Tierney et al. (2010), and (J) MBT-CBTderived MAAT estimates using a 'local SPM' calibration (see section 4.2), in all cases for both IPL and CL brGDGTs. The right $\mathrm{y}$-axis in $(\mathrm{H})$ shows CBT-inferred $\mathrm{pH}$. 
Buckles et al., Geochim. Cosmochim. Acta 140, 106-126 (2014)
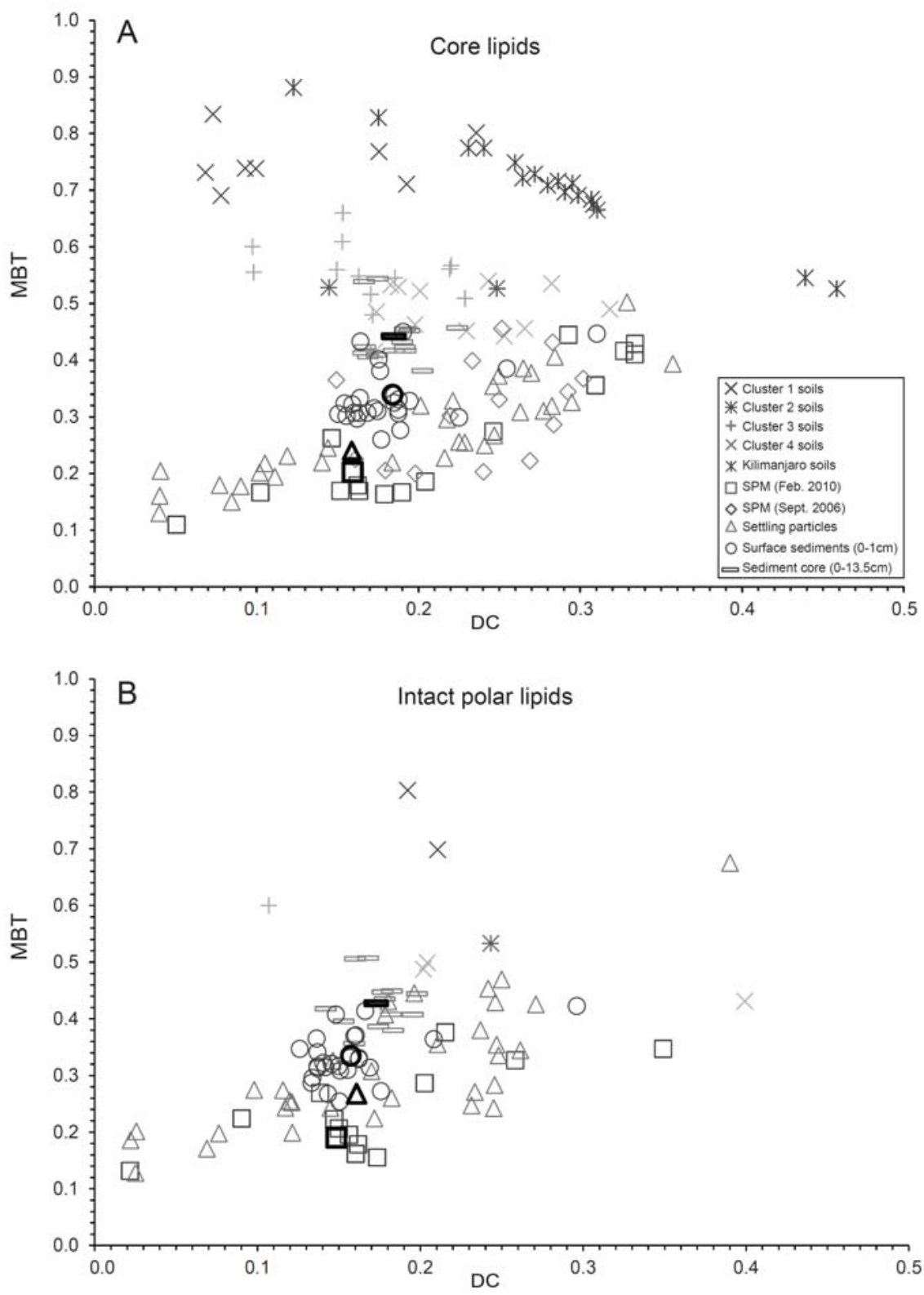

Figure 3: MBT versus DC for the CL (A) and IPL (B) fractions of brGDGTs in individual samples from in and around Lake Challa (this study), as well as Mt. Kilimanjaro soil data (Sinninghe Damsté et al., 2008). Details on the attribution of soil samples to clusters 1-4 are given in Table 1. The mean distributions (centroids) of each sample type are indicated by bold-line symbols; the SPM mean distribution is calculated using 10 evenly-spaced samples throughout the water column; for settling particles it is a flux-weighted average over our 33 months of observation. Samples are plotted using DC as primary $\mathrm{x}$-axis since the CBT ratio is on a logarithmic scale. 
Buckles et al., Geochim. Cosmochim. Acta 140, 106-126 (2014)
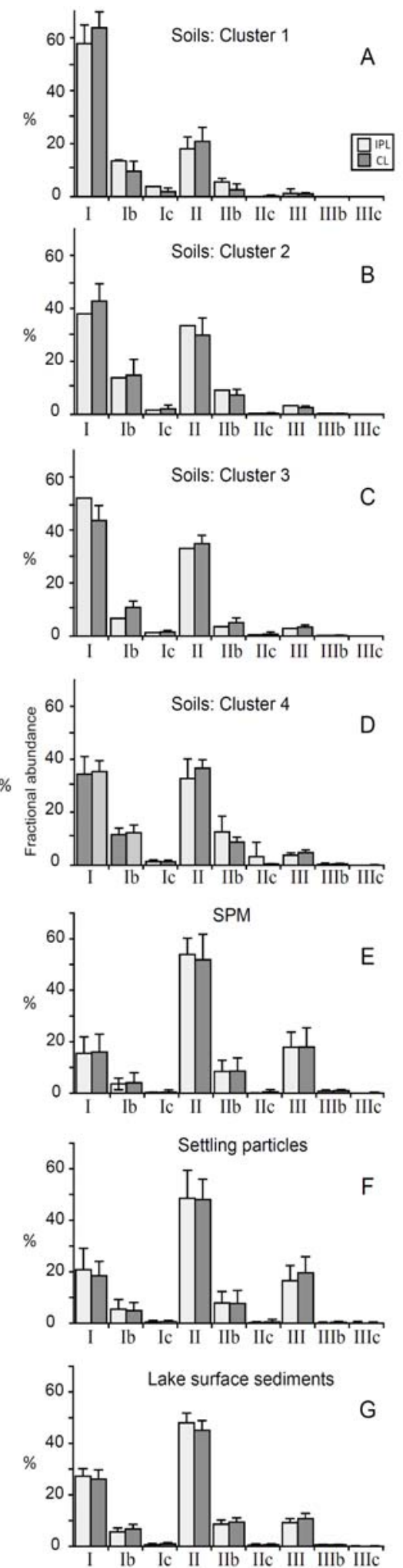

Figure 4: Fractional abundance (\% o f total) of individual brGDGTs in IPL and CL fractions for each major set of samples. All soil distributions (A-D) are based on mean values. SPM distributions (E) are the means of 10 evenly-spaced samples throughout the vertical SPM profile [surface, 9, 19, 29, 39, 49, 59, 69, 79 and $89.4 \mathrm{~m}$ ]. The distributions in settling particles (F) are the means of 24 observations over two full years of measurement (2008-2009). Roman numerals refer to the chemical structures in the Appendix and error bars represent the standard deviation. 

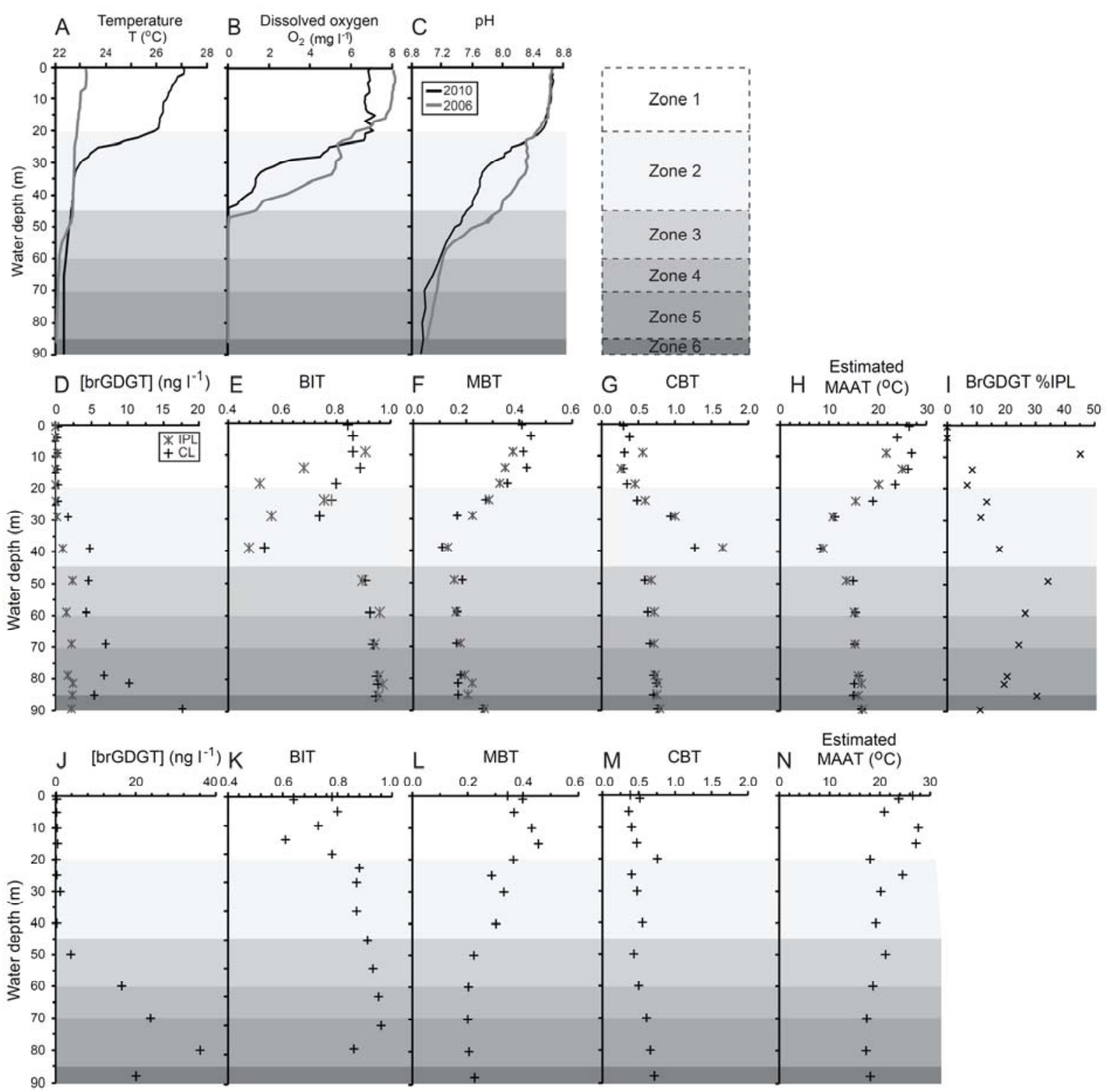

Figure 5: (A) Water temperature, (B) dissolved oxygen and (C) $\mathrm{pH}$ in the water column of Lake Challa, recorded with a Hydrolab Quanta multiprobe within two days of the SPM sampling in February 2010 and September 2006 (data previously reported by Buckles et al., 2013 and Sinninghe Damsté et al., 2009). February 2010 profiles of brGDGT distribution in SPM throughout the water column of Lake Challa include (D) CL and IPL brGDGT concentrations, (E) BIT index (F) MBT index, (G) CBT ratio, (H) MBT/CBT-derived MAAT estimate using the Tierney et al. (2010) East African lake calibration, and (I) \%IPL of brGDGTs. The same profiles for September 2006 (J-N; data from Sinninghe Damsté et al., 2009), except \%IPL, are given for comparison. Grey shading highlights different zones of the water column with different mixing frequencies and physicochemical characteristics (see section 3.2 for details). 
Buckles et al., Geochim. Cosmochim. Acta 140, 106-126 (2014)

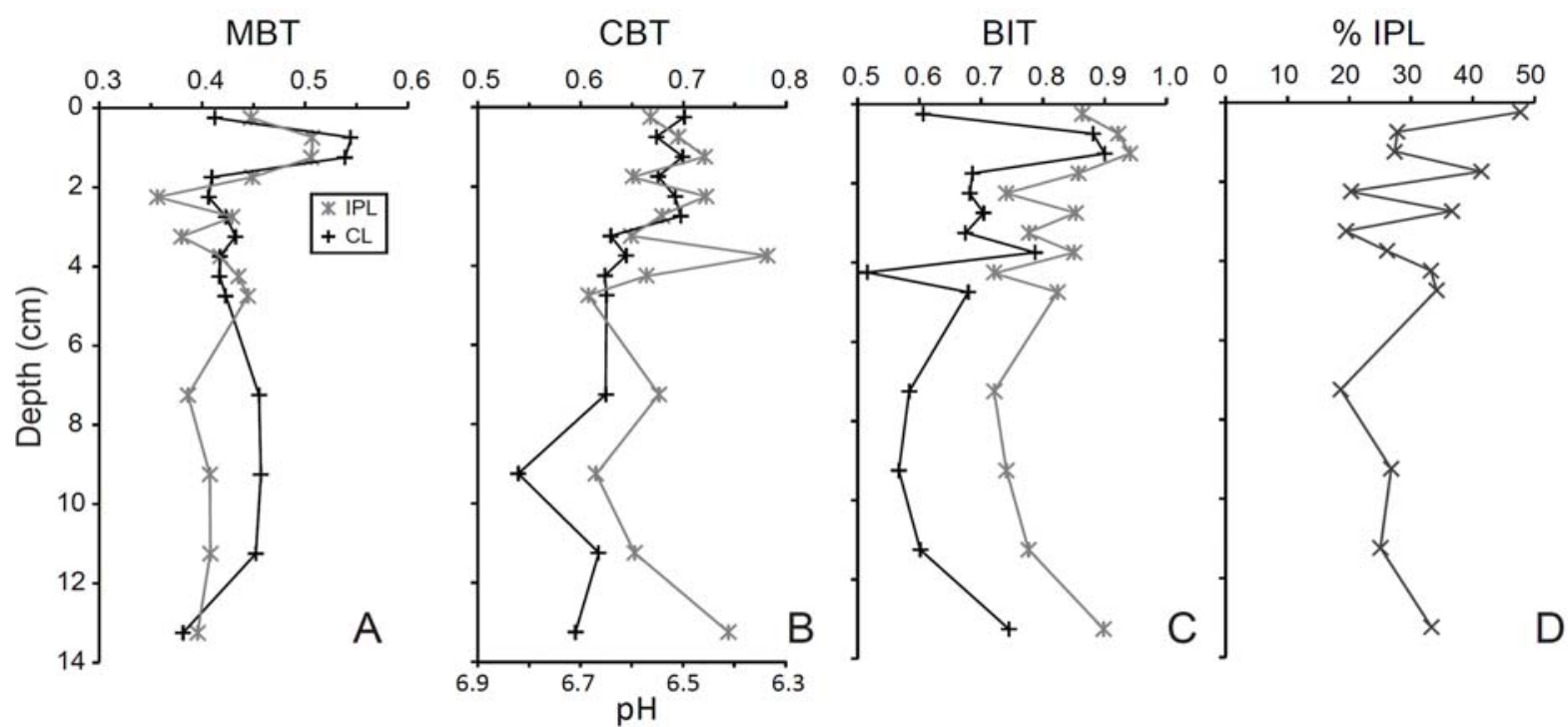

Figure 6: MBT index (A), CBT ratio (B), BIT index (C) and \%IPL (D) for CL and IPL brGDGTs versus depth in sediment core CH08-1G $(0-13.5 \mathrm{~cm})$. The lower y-axis in $(\mathrm{B})$ shows $\mathrm{CBT}$-inferred $\mathrm{pH}$. 
Buckles et al., Geochim. Cosmochim. Acta 140, 106-126 (2014)
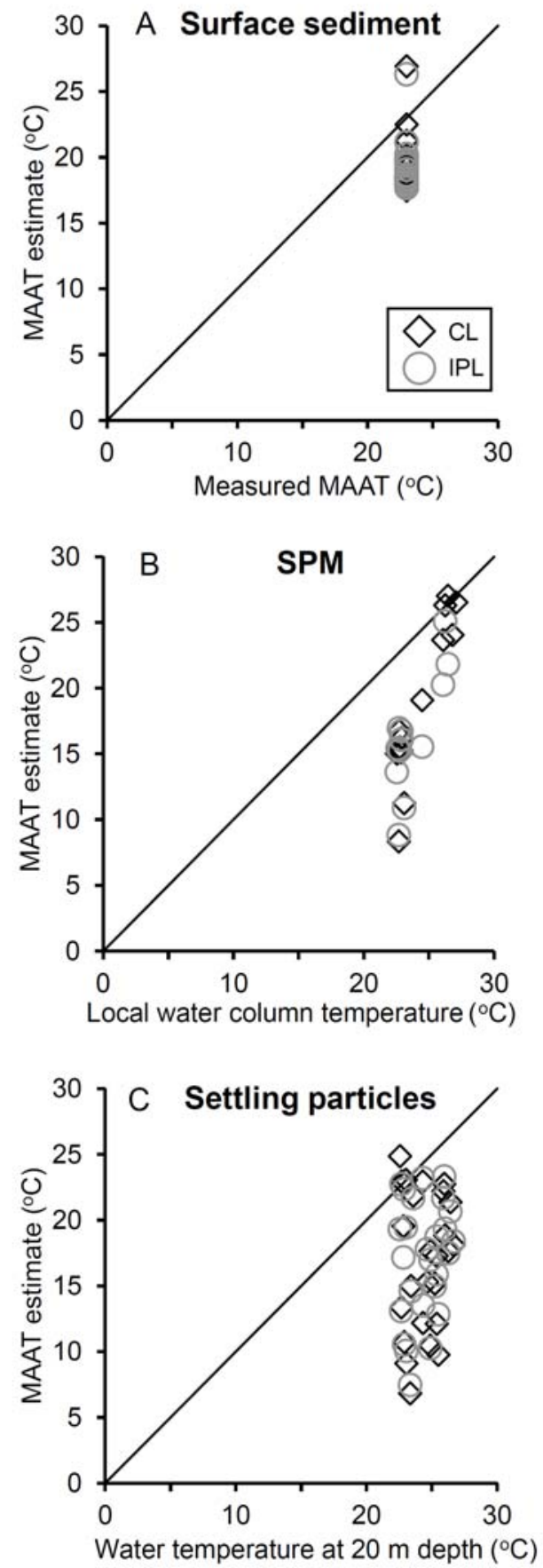

Figure 7: BrGDGT-derived MAAT estimates using the Tierney et al. (2010) lake calibration from (A) bottom surface sediment samples vs. measured lake-side MAAT; (B) SPM vs. the depth gradient of water temperature measured at the time of SPM collection; and (C) settling particles vs. mean monthly lake water temperature measured at $20 \mathrm{~m}$ depth. The solid line represents 1:1 equality. 
Buckles et al., Geochim. Cosmochim. Acta 140, 106-126 (2014)

A Water column temperature - IPL

$r^{2}=0.91$

$\mathrm{n}=6$

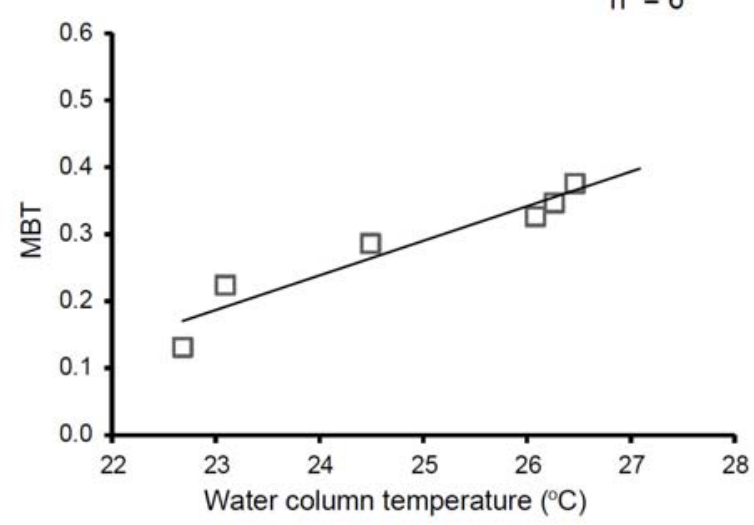

B Water column temperature - $\mathrm{CL}$

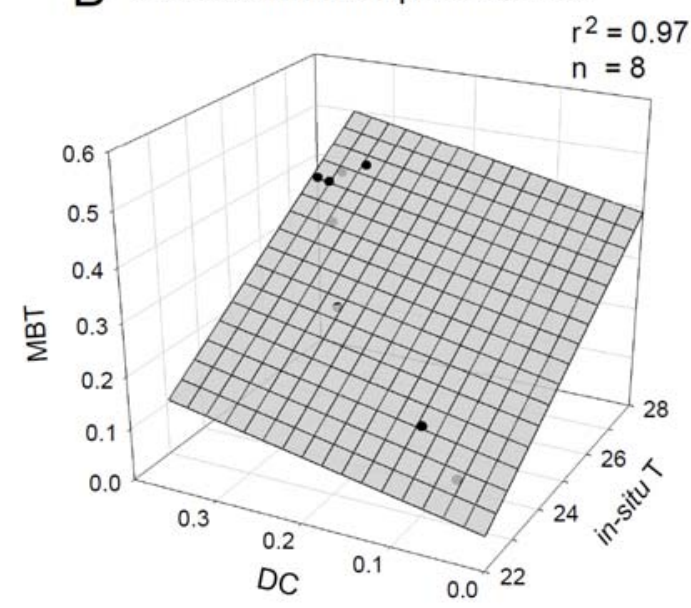

$\mathrm{MBT}=0.0517 \mathrm{~T}-1.002$

MBT $=-1.119+0.0539 T+0.314 \mathrm{DC}$

C Water column $\mathrm{pH}-\mathrm{CL}$

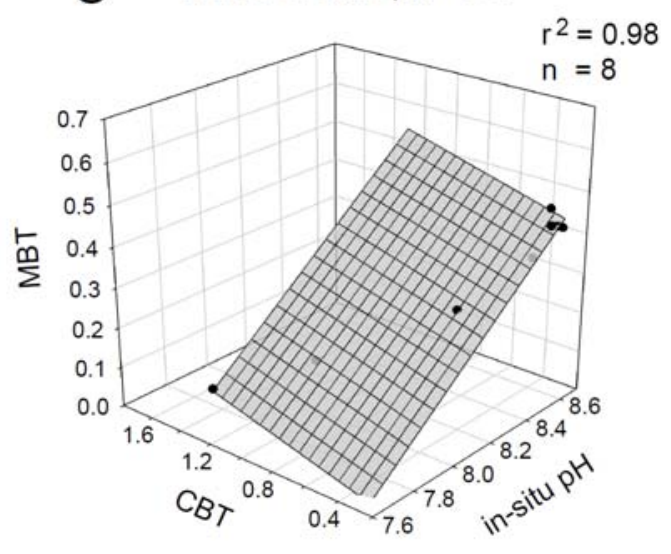

D Water column $\mathrm{pH}$ - IPL

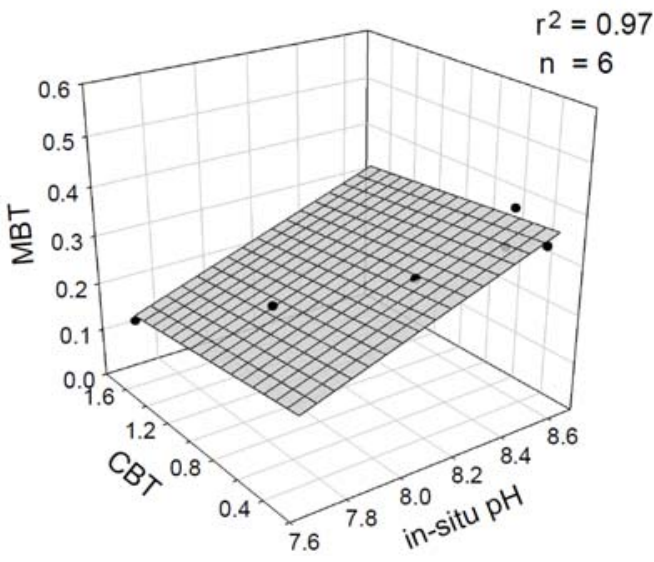

$M B T=-3.399+0.438 p H+0.115 C B T$

Figure 8: SPM-derived MBT vs. local water column temperature and DC for (A) IPL brGDGTs and (B) CL brGDGTs; and SPM-derived MBT vs. local pH and CBT for (C) CL and (D) IPL brGDGTs. 
Appendix Structures of brGDGTs analysed in this study.

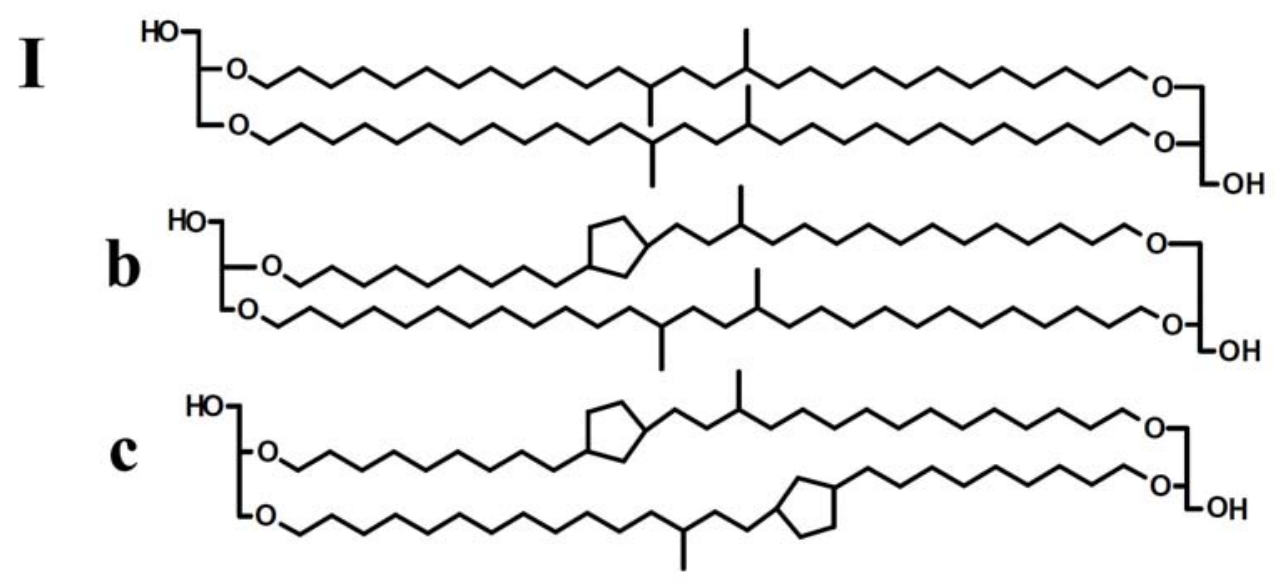

II

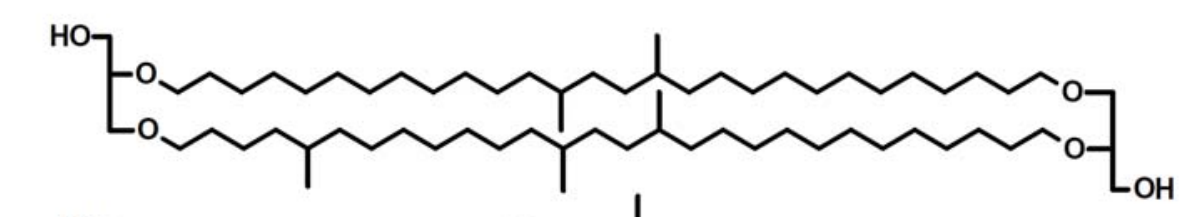
$\mathbf{b}^{\mathrm{H}}$

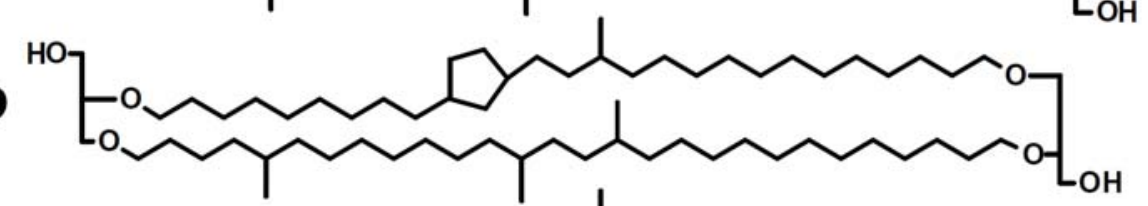

c

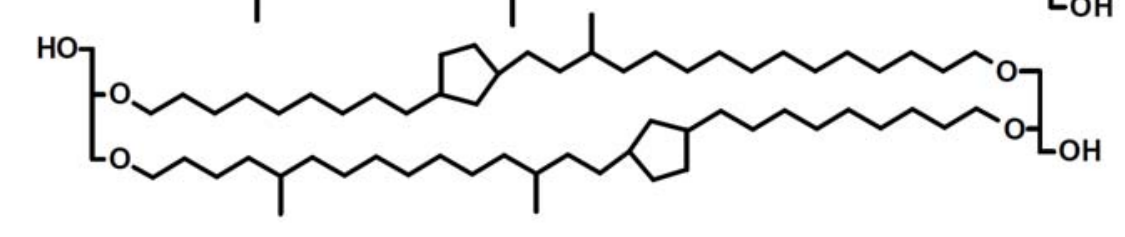

III

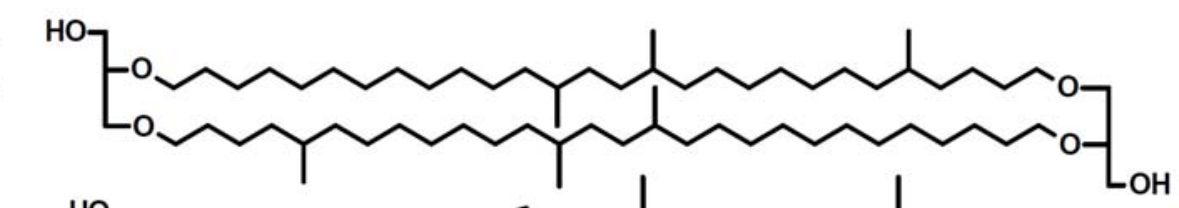

b

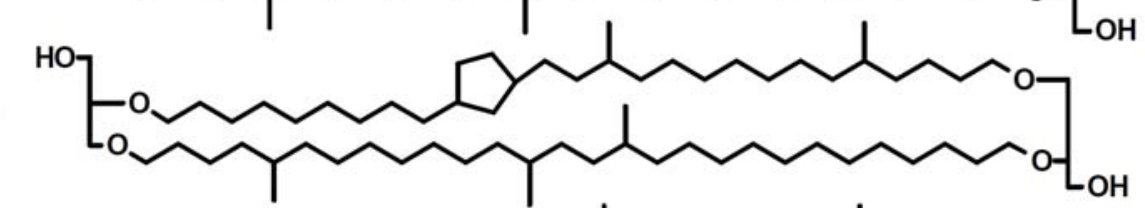

c

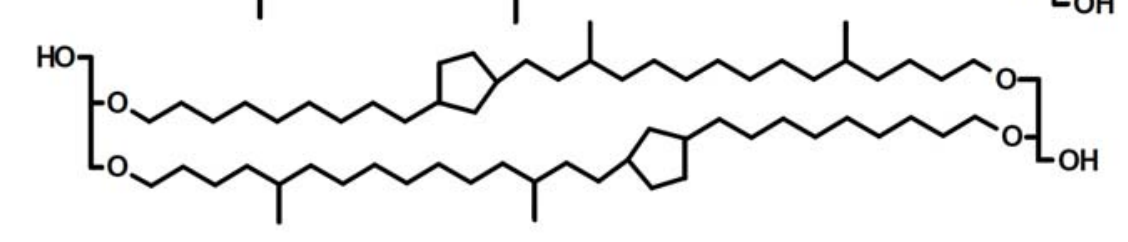

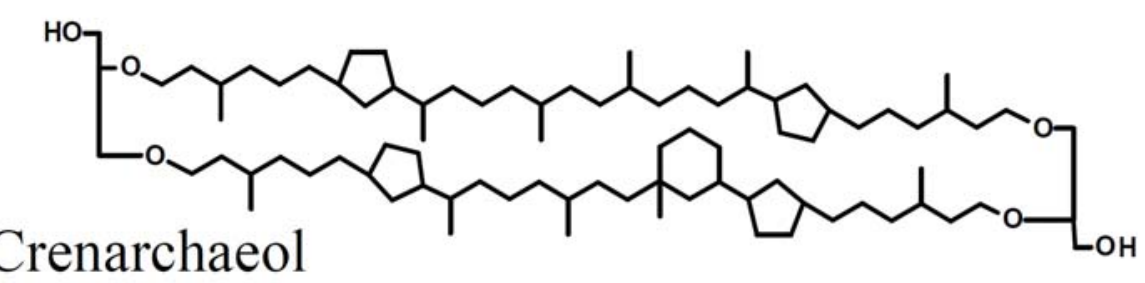


Table 1: Type of samples studied, their $\mathrm{C}_{\text {org }}$ content, mean values of both CL and IPL summed brGDGT and crenarchaeol abundances, and \%IPL values.

\begin{tabular}{|c|c|c|c|c|c|c|c|c|c|}
\hline \multirow[t]{3}{*}{ Sample type } & \multicolumn{2}{|c|}{$\mathrm{n}^{\mathrm{a}}$} & \multirow{3}{*}{$\begin{array}{l}\mathrm{C}_{\text {org }} \\
(\%) \\
\end{array}$} & \multicolumn{3}{|c|}{$\Sigma$ brGDGT } & \multicolumn{3}{|c|}{ Crenarchaeol } \\
\hline & & & & \multicolumn{2}{|c|}{ abundance $^{b}$} & \multirow[t]{2}{*}{$\% \mathrm{IPL}$} & \multicolumn{2}{|c|}{ abundance $^{b}$} & \multirow[t]{2}{*}{$\% \mathrm{IPL}$} \\
\hline & $\mathrm{IPL}$ & $\mathrm{CL}$ & & IPL & $\mathrm{CL}$ & & IPL & $\mathrm{CL}$ & \\
\hline Soil cluster 1 & 2 & 8 & 1.4 & 0.5 & 2.8 & 12 & 0.8 & 0.2 & 72 \\
\hline Soil cluster 2 & 1 & 3 & 2.2 & 0.4 & 8.4 & 6 & 0.5 & 0.9 & 58 \\
\hline Soil cluster 3 & 1 & 12 & 2.1 & 0.3 & 3.1 & 10 & 0.6 & 0.9 & 50 \\
\hline Soil cluster 4 & 3 & 12 & 8.9 & 0.1 & 2.6 & 7 & 0.4 & 1.3 & 33 \\
\hline SPM 0-20 $\mathrm{m}^{\mathrm{c}}$ & 2 & 3 & n.d. ${ }^{d}$ & 0.1 & 0.4 & 20 & 0.0 & 0.0 & 22 \\
\hline SPM $21-45 \mathrm{~m}^{\mathrm{c}}$ & 2 & 2 & n.d. & 0.6 & 3.3 & 16 & 0.6 & 2.3 & 22 \\
\hline SPM 46-60 m & 2 & 2 & n.d. & 2.0 & 4.4 & 31 & 0.1 & 0.3 & 30 \\
\hline SPM $61-70 \mathrm{~m}^{\mathrm{c}}$ & 1 & 1 & n.d. & 2.2 & 7.0 & 23 & 0.1 & 0.4 & 24 \\
\hline SPM 71-85 $\mathrm{m}^{\mathrm{c}}$ & 1 & 1 & n.d. & 1.7 & 6.8 & 18 & 0.1 & 0.3 & 20 \\
\hline $\mathrm{SPM} 89.4 \mathrm{~m}^{\mathrm{c}}$ & 1 & 1 & n.d & 2.2 & 17.6 & 11 & 0.1 & 1.1 & 10 \\
\hline Settling particles ${ }^{\mathrm{e}}$ & 24 & 24 & 14.7 & 0.4 & 1.4 & 20 & 0.2 & 0.8 & 19 \\
\hline Sediments $(0-1 \mathrm{~cm})$ & 24 & 24 & 8.9 & 18.9 & 86.9 & 18 & 1.9 & 9.3 & 19 \\
\hline
\end{tabular}

\footnotetext{
${ }^{a}$ number of samples

${ }^{\mathrm{b}}$ concentration in $\mu \mathrm{g} \mathrm{g}^{-1} \mathrm{C}_{\text {org }}$ for soils and sediments and in $\mathrm{ng}^{-1}$ for SPM, and accumulation rate ( $\mu \mathrm{g} \mathrm{m}^{-2}$ day $^{-1}$ ) for settling particles

${ }^{c}$ values from SPM (February 2010) are abundance-weighted and based on summed, relatively evenlyspaced concentrations over the SPM profile

${ }^{\mathrm{d}}$ n.d. $=$ not determined

${ }^{\mathrm{e}}$ values from settling particles are flux-weighted means, calculated based on a summed flux of all sampled settling particles over the period 31/12/2007 - 27/12/2009.
} 
Buckles et al., Geochim. Cosmochim. Acta 140, 106-126 (2014)

Table 2: Mean values of the MBT, CBT and BIT indices of different sample types for both IPL and CL fractions.

\begin{tabular}{lcccccccc}
\hline \multirow{2}{*}{ Sample type } & \multicolumn{2}{c}{$\mathrm{n}^{\mathrm{a}}$} & \multicolumn{2}{c}{ MBT } & \multicolumn{2}{c}{ CBT } & \multicolumn{2}{c}{ BIT } \\
& IPL & CL & IPL & CL & IPL & CL & IPL & CL \\
\hline Soil cluster 1 & 2 & 8 & 0.75 & 0.75 & 0.60 & 0.88 & 0.35 & 0.91 \\
Soil cluster 2 & 1 & 3 & 0.53 & 0.57 & 0.49 & 0.44 & 0.38 & 0.88 \\
Soil cluster 3 & 1 & 12 & 0.60 & 0.56 & 0.92 & 0.71 & 0.29 & 0.75 \\
Soil cluster 4 & 3 & 12 & 0.47 & 0.49 & 0.34 & 0.54 & 0.25 & 0.64 \\
SPM 0-20 m & 2 & 3 & 0.37 & 0.39 & 0.55 & 0.32 & 0.84 & 0.83 \\
SPM 21-45 m & 2 & 2 & 0.15 & 0.12 & 1.45 & 1.16 & 0.49 & 0.58 \\
SPM 46-60 m & 2 & 2 & 0.16 & 0.18 & 0.69 & 0.61 & 0.92 & 0.91 \\
SPM 61-70 mb & 1 & 1 & 0.18 & 0.16 & 0.71 & 0.66 & 0.94 & 0.93 \\
SPM 71-85 m & 1 & 1 & 0.20 & 0.18 & 0.73 & 0.71 & 0.96 & 0.95 \\
SPM 89.4 m & 1 & 1 & 0.27 & 0.26 & 0.79 & 0.77 & 0.94 & 0.93 \\
Settling particles & 24 & 24 & 0.27 & 0.24 & 0.72 & 0.73 & 0.64 & 0.62 \\
Sediments $(0-1 \mathrm{~cm})$ & 24 & 24 & 0.33 & 0.34 & 0.73 & 0.65 & 0.92 & 0.90 \\
\hline
\end{tabular}

\footnotetext{
${ }^{a}$ number of samples

${ }^{\mathrm{b}}$ values from SPM (February 2010) are abundance-weighted and based on summed, relatively evenlyspaced concentrations over the SPM profile

${ }^{\mathrm{c}}$ values from settling particles are flux-weighted means, calculated based on a summed flux of all sampled settling particles over time
} 
Table 3: Average temperature estimates (with standard deviation in brackets) using different calibrations applied to the various sample types.

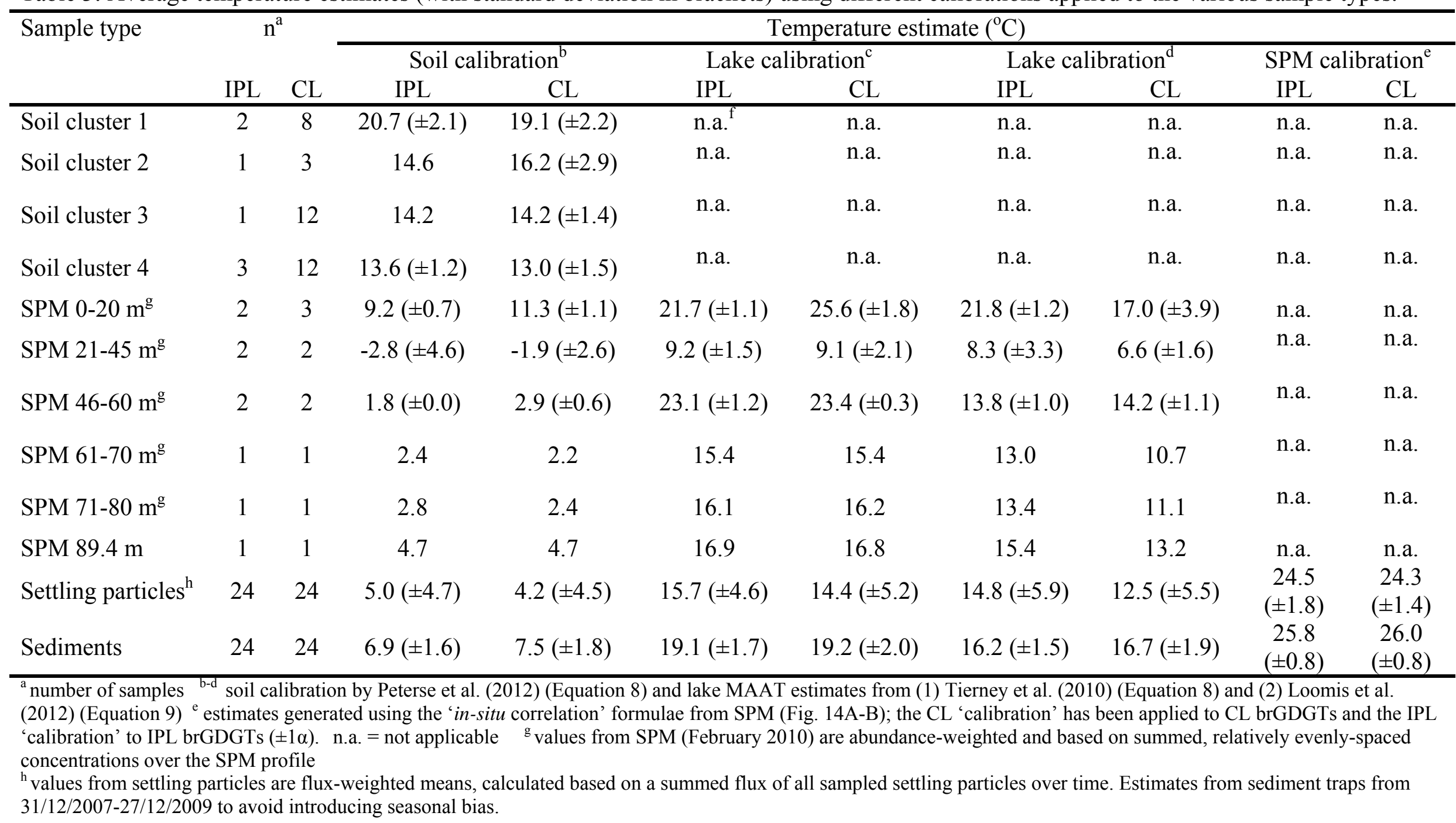


Table 4: Linear correlations $\left(\mathrm{r}^{2}\right)$ between February 2010 SPM-derived IPL and CL MBT, DC/CBT, in-situ pH and in-situ temperatures.

\begin{tabular}{|c|c|c|c|c|c|c|c|c|}
\hline & \multicolumn{4}{|c|}{ Full profile; $n=15^{a}$} & \multicolumn{4}{|c|}{ Above $45 \mathrm{~m} ; \mathrm{n}=8^{\mathrm{b}}$} \\
\hline & \multicolumn{2}{|c|}{ IPL } & \multicolumn{2}{|c|}{$\mathrm{CL}$} & \multicolumn{2}{|c|}{ IPL } & \multicolumn{2}{|c|}{$\mathrm{CL}$} \\
\hline & MBT & $\begin{array}{c}\mathrm{DC} / \\
\mathrm{CBT}^{\mathrm{c}} \\
\end{array}$ & MBT & $\begin{array}{l}\mathrm{DC} / \\
\mathrm{CBT} \\
\end{array}$ & MBT & $\begin{array}{l}\mathrm{DC} / \\
\mathrm{CBT} \\
\end{array}$ & MBT & $\begin{array}{l}\mathrm{DC} / \\
\mathrm{CBT} \\
\end{array}$ \\
\hline Temp. & 0.82 & 0.59 & 0.91 & 0.80 & 0.91 & 0.81 & 0.96 & 0.91 \\
\hline $\mathrm{pH}$ & 0.55 & 0.21 & 0.57 & 0.37 & 0.59 & 0.60 & 0.50 & 0.54 \\
\hline
\end{tabular}

${ }^{\mathrm{a}}$ number of samples between $0.5-89.4 \mathrm{~m}$ depth

${ }^{\mathrm{b}}$ number of samples between $0.5-39 \mathrm{~m}$ depth

${ }^{\mathrm{c}} \mathrm{DC}$ to temperature (linear variable) and $\mathrm{CBT}$ to $\mathrm{pH}$ (logarithmic). 


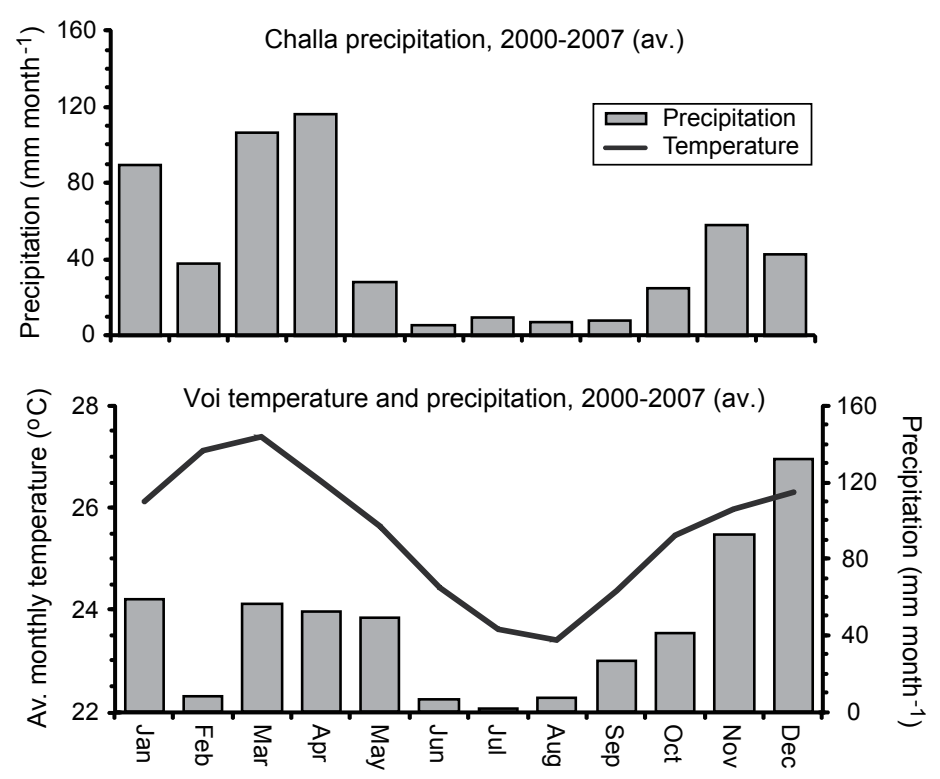

Figure S1: Average monthly precipitation at the Challa agricultural station north of Lake Challa (2000-2007) and average monthly temperature (bold line) and precipitation at Voi (2000-2007), $80 \mathrm{~km}$ to the east of Lake Challa. 

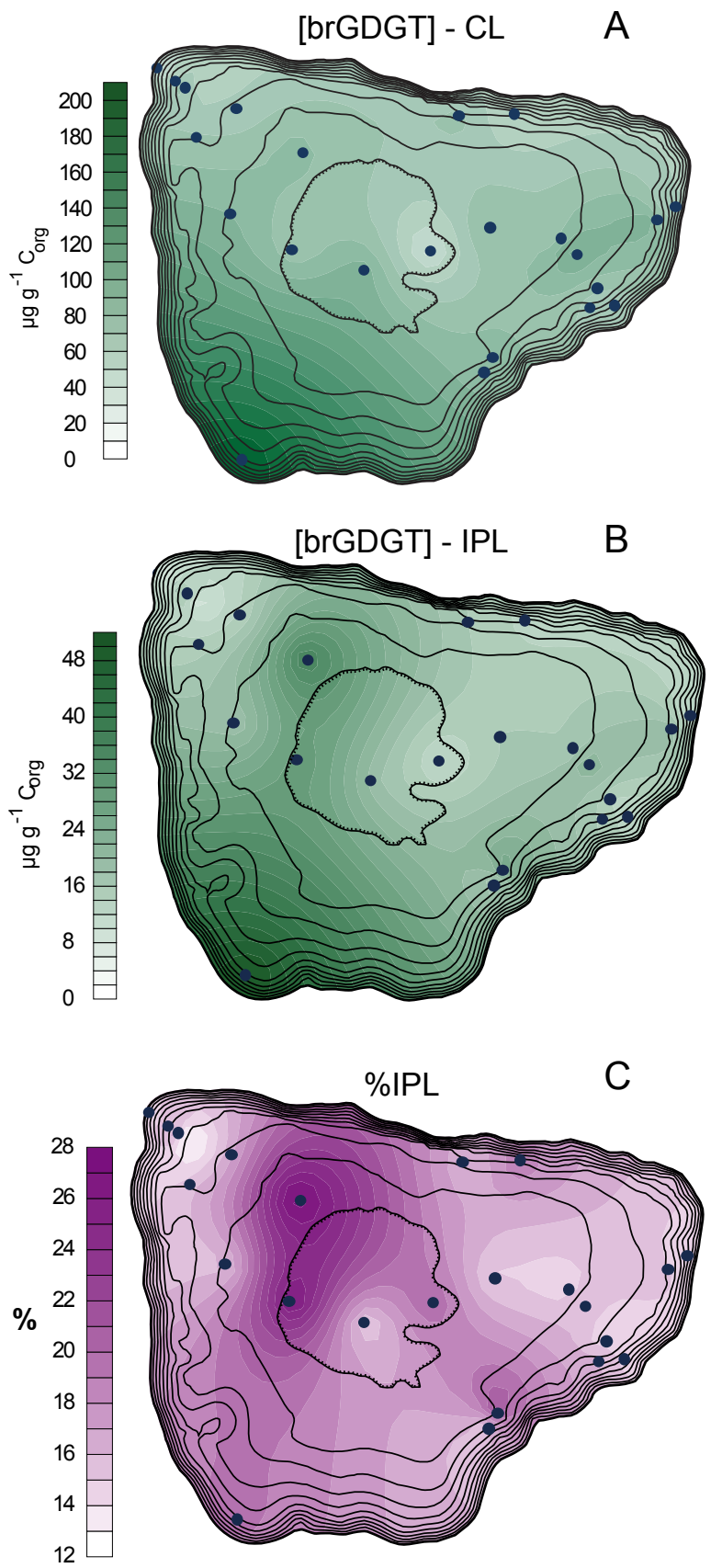

Figure S2: Spatial distribution of IPL and CL brGDGT concentrations (A-B) and \%IPL (C) in bottom surface sediments of Lake Challa. Bathymetry (black contour lines) scaled as in Fig.1. 
Supplementary Table 1: Location and general characteristics of soil samples around Lake Challa and their GDGT data.

\begin{tabular}{|c|c|c|c|c|c|c|c|c|c|c|c|c|c|c|c|c|c|c|c|c|}
\hline \multicolumn{2}{|c|}{ UTM coordinates } & \multirow[t]{2}{*}{ Colour } & \multirow[t]{2}{*}{$\begin{array}{c}\text { Depth } \\
\text { interval } \\
(\mathrm{cm})\end{array}$} & \multirow[t]{2}{*}{ Origin } & \multirow[t]{2}{*}{ Cluster } & \multirow[t]{2}{*}{$\% \mathrm{C}_{\text {org }}$} & \multicolumn{2}{|c|}{ 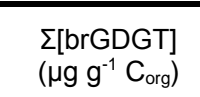 } & \multirow[t]{2}{*}{$\begin{array}{c}\% \text { IPL } \\
\Sigma(\text { brGDGT })\end{array}$} & \multicolumn{2}{|c|}{ MBT } & \multicolumn{2}{|c|}{ CBT } & \multicolumn{2}{|c|}{ BIT } & \multicolumn{2}{|c|}{$\operatorname{MAAT}^{\mathrm{a}}\left({ }^{\circ} \mathrm{C}\right)$} & \multicolumn{2}{|c|}{$\begin{array}{r}\text { [Crenarchaeol] } \\
\left(\mu \mathrm{g} \mathrm{g}^{-1} \mathrm{C}_{\text {org }}\right)\end{array}$} & \multirow[t]{2}{*}{$\begin{array}{l}\% I P L \\
\text { Cren. }\end{array}$} \\
\hline Easting & Northing & & & & & & $\mathrm{IPL}$ & $\mathrm{CL}$ & & $\mathrm{IPL}$ & $\mathrm{CL}$ & $\mathrm{IPL}$ & $\mathrm{CL}$ & $\mathrm{IPL}$ & $\mathrm{CL}$ & $\mathrm{IPL}$ & $\mathrm{CL}$ & $\mathrm{IPL}$ & $\mathrm{CL}$ & \\
\hline 348304 & 9635591 & red & $0-8$ & $\mathrm{H}$ & 1 & 1.1 & 0.8 & 4.1 & 16 & 0.70 & 0.71 & 0.57 & 0.62 & 0.29 & 0.89 & 19.2 & 19.3 & 1.5 & 0.4 & 80 \\
\hline 348304 & 9635591 & red & $0-7$ & $\mathrm{H}$ & 1 & 0.5 & n.d. ${ }^{b}$ & 3.3 & n.d. & n.d. & 0.77 & n.d. & 0.67 & n.d. & 0.88 & n.d. & 20.8 & n.d. & 0.4 & n.d. \\
\hline 348483 & 9638806 & red & $0-8$ & $\mathrm{H}$ & 1 & 0.6 & 0.2 & 2.4 & 7 & 0.80 & 0.80 & 0.62 & 0.51 & 0.41 & 0.94 & 22.2 & 22.8 & 0.2 & 0.1 & 64 \\
\hline 348483 & 9638806 & red & $0-7$ & $\mathrm{H}$ & 1 & 1.5 & n.d. & 2.0 & n.d. & n.d. & 0.73 & n.d. & 1.13 & n.d. & 0.91 & n.d. & 17.1 & n.d. & 0.2 & n.d. \\
\hline 354034 & 9634638 & red & n.d. & $\mathrm{RH}$ & 1 & 2.2 & n.d. & 2.5 & n.d. & n.d. & 0.74 & n.d. & 0.99 & n.d. & 0.89 & n.d. & 18.1 & n.d. & 0.3 & n.d. \\
\hline 354100 & 9634280 & red & $0-6$ & $\mathrm{RH}$ & 1 & 2.6 & n.d. & 2.7 & n.d. & n.d. & 0.74 & n.d. & 0.96 & n.d. & 0.92 & n.d. & 18.3 & n.d. & 0.2 & n.d. \\
\hline 354373 & 9634504 & red & n.d. & $\mathrm{RH}$ & 1 & 1.2 & n.d. & 4.3 & n.d. & n.d. & 0.83 & n.d. & 1.10 & n.d. & 0.94 & n.d. & 20.4 & n.d. & 0.3 & n.d. \\
\hline 354378 & 9634454 & red & $0-10$ & $\mathrm{RH}$ & 1 & 1.6 & n.d. & 1.2 & n.d. & n.d. & 0.69 & n.d. & 1.07 & n.d. & 0.88 & n.d. & 16.2 & n.d. & 0.2 & n.d. \\
\hline 354074 & 9634752 & red & $0-10$ & $\mathrm{RH}$ & 2 & 3.0 & n.d. & 7.6 & n.d. & n.d. & 0.53 & n.d. & 0.48 & n.d. & 0.88 & n.d. & 14.5 & n.d. & 0.8 & n.d. \\
\hline 354312 & 9634167 & red & $0-6$ & LR & 2 & 1.9 & 0.4 & 6.6 & 6 & 0.53 & 0.53 & 0.49 & 0.49 & 0.38 & 0.93 & 14.6 & 14.5 & 0.5 & 0.5 & 58 \\
\hline 354312 & 9634167 & red & $0-6$ & LR & 2 & 1.7 & n.d. & 10.9 & n.d. & n.d. & 0.67 & n.d. & 0.35 & n.d. & 0.83 & n.d. & 19.5 & n.d. & 1.5 & n.d. \\
\hline 354127 & 9632457 & red & n.d. & C & 3 & 3.0 & n.d. & 2.1 & n.d. & n.d. & 0.55 & n.d. & 0.71 & n.d. & 0.76 & n.d. & 13.8 & n.d. & 0.5 & n.d. \\
\hline 354131 & 9632427 & grey & $0-6$ & $C$ & 3 & 1.6 & n.d. & 3.8 & n.d. & n.d. & 0.52 & n.d. & 0.69 & n.d. & 0.69 & n.d. & 13.0 & n.d. & 1.4 & n.d. \\
\hline 354189 & 9634616 & red & $0-10$ & $\mathrm{RCH}$ & 3 & 1.8 & n.d. & 2.5 & n.d. & n.d. & 0.56 & n.d. & 0.96 & n.d. & 0.75 & n.d. & 12.6 & n.d. & 0.7 & n.d. \\
\hline 354385 & 9632065 & grey/red & $0-6$ & $C$ & 3 & 2.0 & n.d. & 1.6 & n.d. & n.d. & 0.66 & n.d. & 0.74 & n.d. & 0.85 & n.d. & 17.1 & n.d. & 0.2 & n.d. \\
\hline 354570 & 9634400 & red & $0-6$ & $\mathrm{C}$ & 3 & 1.2 & n.d. & 3.4 & n.d. & n.d. & 0.61 & n.d. & 0.74 & n.d. & 0.81 & n.d. & 15.5 & n.d. & 0.6 & n.d. \\
\hline 354990 & 9632000 & grey & $0-6$ & C & 3 & 1.3 & n.d. & 3.7 & n.d. & n.d. & 0.57 & n.d. & 0.55 & n.d. & 0.75 & n.d. & 15.3 & n.d. & 0.9 & n.d. \\
\hline 355400 & 9632018 & grey & $0-6$ & $\mathrm{C}$ & 3 & 1.6 & n.d. & 3.5 & n.d. & n.d. & 0.56 & n.d. & 0.55 & n.d. & 0.74 & n.d. & 15.1 & n.d. & 0.9 & n.d. \\
\hline 355620 & 9634192 & grey & $0-6$ & $\mathrm{C}$ & 3 & 1.7 & 0.3 & 2.5 & 10 & 0.60 & 0.60 & 0.92 & 0.97 & 0.29 & 0.78 & 14.2 & 14.0 & 0.6 & 0.8 & 50 \\
\hline 355846 & 9632140 & grey & $0-6$ & C & 3 & 0.6 & n.d. & 4.3 & n.d. & n.d. & 0.48 & n.d. & 0.68 & n.d. & 0.64 & n.d. & 11.8 & n.d. & 2.0 & n.d. \\
\hline 356283 & 9634184 & grey & $0-6$ & C & 3 & 2.4 & n.d. & 3.3 & n.d. & n.d. & 0.55 & n.d. & 0.64 & n.d. & 0.77 & n.d. & 14.1 & n.d. & 0.8 & n.d. \\
\hline 356688 & 9634076 & grey & $0-6$ & C & 3 & 4.1 & n.d. & 4.4 & n.d. & n.d. & 0.51 & n.d. & 0.53 & n.d. & 0.72 & n.d. & 13.7 & n.d. & 1.3 & n.d. \\
\hline 356939 & 9633885 & grey & $0-7$ & $\mathrm{C}$ & 3 & 3.7 & n.d. & 2.3 & n.d. & n.d. & 0.56 & n.d. & 0.75 & n.d. & 0.74 & n.d. & 13.9 & n.d. & 0.6 & n.d. \\
\hline 354000 & 9633520 & red & $0-6$ & $\mathrm{C}$ & 4 & 3.2 & n.d. & 2.1 & n.d. & n.d. & 0.54 & n.d. & 0.49 & n.d. & 0.51 & n.d. & 14.8 & n.d. & 1.5 & n.d. \\
\hline 354050 & 9632970 & grey & $0-6$ & C & 4 & 3.2 & 0.2 & 2.1 & 9 & 0.50 & 0.52 & 0.26 & 0.60 & 0.16 & 0.68 & 14.9 & 13.7 & 0.8 & 0.8 & 51 \\
\hline 354200 & 9634220 & red & $0-8$ & $\mathrm{RC}$ & 4 & 4.3 & 0.1 & 1.3 & 6 & 0.43 & 0.54 & 0.18 & 0.41 & 0.24 & 0.66 & 13.3 & 15.3 & 0.1 & 0.9 & 24 \\
\hline 354350 & 9633160 & grey & $0-4$ & L & 4 & 12.5 & n.d. & 3.7 & n.d. & n.d. & 0.46 & n.d. & 0.44 & n.d. & 0.69 & n.d. & 12.5 & n.d. & 1.3 & n.d. \\
\hline 354750 & 9634350 & grey & $0-6$ & C & 4 & 1.9 & n.d. & 2.0 & n.d. & n.d. & 0.53 & n.d. & 0.65 & n.d. & 0.51 & n.d. & 13.7 & n.d. & 1.5 & n.d. \\
\hline 355418 & 9634165 & grey & $0-6$ & L & 4 & 6.9 & 0.1 & 1.2 & 5 & 0.49 & 0.46 & 0.60 & 0.61 & 0.37 & 0.75 & 12.5 & 11.8 & 0.1 & 0.3 & 23 \\
\hline 356218 & 9632743 & grey & n.d. & $\mathrm{CL}$ & 4 & 8.4 & n.d. & 5.3 & n.d. & n.d. & 0.49 & n.d. & 0.33 & n.d. & 0.63 & n.d. & 14.3 & n.d. & 2.1 & n.d. \\
\hline 356422 & 9634031 & grey & 3-3.5 & L & 4 & 10.1 & n.d. & 1.2 & n.d. & n.d. & 0.49 & n.d. & 0.68 & n.d. & 0.76 & n.d. & 12.1 & n.d. & 0.3 & n.d. \\
\hline 356434 & 9632906 & grey & $5-20$ & L & 4 & 21.8 & n.d. & 2.4 & n.d. & n.d. & 0.53 & n.d. & 0.64 & n.d. & 0.73 & n.d. & 13.7 & n.d. & 0.7 & n.d. \\
\hline 356937 & 9633555 & grey & $0-6$ & $\mathrm{CL}$ & 4 & 24.7 & n.d. & 1.6 & n.d. & n.d. & 0.42 & n.d. & 0.68 & n.d. & 0.78 & n.d. & 9.9 & n.d. & 0.4 & n.d. \\
\hline 356950 & 9633581 & grey & $0-3$ & $\mathrm{~L}$ & 4 & 5.4 & n.d. & 3.5 & n.d. & n.d. & 0.45 & n.d. & 0.53 & n.d. & 0.52 & n.d. & 11.9 & n.d. & 2.6 & n.d. \\
\hline 356967 & 9633547 & grey & $3-10$ & $\mathrm{CL}$ & 4 & 3.7 & n.d. & 4.9 & n.d. & n.d. & 0.44 & n.d. & 0.47 & n.d. & 0.52 & n.d. & 12.0 & n.d. & 3.3 & n.d. \\
\hline
\end{tabular}

b n.d. = not determined 
Supplementary Table 2: GDGT data for SPM sampled in Lake Challa in February 2010 at various depth and calculated MAATs using three different calibrations.

\begin{tabular}{|c|c|c|c|c|c|c|c|c|c|c|c|c|c|c|c|}
\hline \multirow[t]{2}{*}{$\begin{array}{l}\text { Water depth } \\
\qquad(\mathrm{m})\end{array}$} & \multicolumn{2}{|c|}{$\begin{array}{c}\Sigma[\mathrm{brGDGT}] \\
\left(\mathrm{ng} \mathrm{l}^{-1}\right)\end{array}$} & \multirow[t]{2}{*}{$\begin{array}{c}\% \text { IPL } \\
\Sigma(\text { brGDGT })\end{array}$} & \multicolumn{2}{|c|}{ MBT } & \multicolumn{2}{|c|}{ CBT } & \multicolumn{2}{|c|}{ BIT } & \multicolumn{2}{|c|}{$\begin{array}{l}\text { MAAT - } \\
\text { soila }\left({ }^{\circ} \mathrm{C}\right)\end{array}$} & \multicolumn{2}{|c|}{$\begin{array}{l}\text { MAAT - } \\
\text { lake }{ }^{\mathrm{b}}\left({ }^{\circ} \mathrm{C}\right)\end{array}$} & \multicolumn{2}{|c|}{$\begin{array}{l}\text { MAAT - } \\
\text { lake }^{\mathrm{c}}\left({ }^{\circ} \mathrm{C}\right)\end{array}$} \\
\hline & $\mathrm{IPL}$ & $\overline{C L}$ & & $\mathrm{IPL}$ & $\mathrm{CL}$ & IPL & $\overline{C L}$ & IPL & $\overline{C L}$ & $\mathrm{IPL}$ & $\overline{C L}$ & $\mathrm{IPL}$ & $\overline{C L}$ & $\mathrm{IPL}$ & $\overline{C L}$ \\
\hline 0.5 & b.d.d & 0.4 & b.d. & b.d. & 0.41 & b.d. & 0.30 & b.d. & 0.84 & b.d. & 11.9 & b.d. & 26.5 & b.d. & 14.3 \\
\hline 4 & b.d. & 0.3 & b.d. & b.d. & 0.44 & b.d. & 0.38 & b.d. & 0.86 & b.d. & 12.4 & b.d. & 24.0 & b.d. & 26.9 \\
\hline 9 & 0.2 & 0.3 & 45 & 0.38 & 0.42 & 0.56 & 0.31 & 0.91 & 0.86 & 9.3 & 12.0 & 21.8 & 27.0 & 22.0 & 21.7 \\
\hline 14 & 0.0 & 0.3 & 9 & 0.35 & 0.43 & 0.27 & 0.30 & 0.68 & 0.89 & 10.0 & 12.5 & 25.1 & 26.3 & 25.6 & 20.9 \\
\hline 19 & 0.0 & 0.4 & 7 & 0.33 & 0.36 & 0.46 & 0.35 & 0.52 & 0.80 & 8.3 & 10.1 & 20.3 & 23.7 & 20.4 & 16.1 \\
\hline 24 & 0.1 & 0.4 & 13 & 0.29 & 0.27 & 0.59 & 0.49 & 0.75 & 0.78 & 6.3 & 6.6 & 15.5 & 19.1 & 16.1 & 12.3 \\
\hline 29 & 0.2 & 1.8 & 11 & 0.22 & 0.17 & 1.00 & 0.94 & 0.56 & 0.74 & 2.1 & 0.7 & 10.9 & 11.3 & 12.1 & 8.2 \\
\hline 39 & 1.0 & 4.8 & 18 & 0.13 & 0.11 & 1.65 & 1.27 & 0.48 & 0.53 & -4.5 & -3.0 & 8.8 & 8.3 & 7.4 & 6.0 \\
\hline 49 & 2.4 & 4.6 & 34 & 0.16 & 0.19 & 0.68 & 0.59 & 0.90 & 0.91 & 1.8 & 3.2 & 13.6 & 15.0 & 11.1 & 12.5 \\
\hline 59 & 1.5 & 4.3 & 27 & 0.16 & 0.17 & 0.72 & 0.63 & 0.96 & 0.92 & 1.8 & 2.4 & 15.3 & 15.5 & 12.4 & 10.9 \\
\hline 69 & 2.2 & 7.0 & 24 & 0.18 & 0.16 & 0.71 & 0.66 & 0.94 & 0.93 & 2.4 & 2.2 & 15.4 & 15.4 & 13.0 & 10.7 \\
\hline 79 & 1.7 & 6.8 & 20 & 0.20 & 0.18 & 0.73 & 0.71 & 0.96 & 0.95 & 2.8 & 2.4 & 16.1 & 16.2 & 13.4 & 11.1 \\
\hline 81.5 & 2.4 & 10.2 & 19 & 0.22 & 0.17 & 0.76 & 0.75 & 0.97 & 0.95 & 3.4 & 1.9 & 16.7 & 15.3 & 14.3 & 11.0 \\
\hline 85 & 2.4 & 5.4 & 30 & 0.21 & 0.17 & 0.75 & 0.71 & 0.95 & 0.95 & 3.0 & 2.1 & 16.1 & 15.1 & 13.9 & 9.9 \\
\hline 89.4 & 2.2 & 17.6 & 11 & 0.27 & 0.26 & 0.79 & 0.77 & 0.94 & 0.93 & 4.7 & 4.7 & 16.9 & 16.8 & 15.4 & 13.2 \\
\hline
\end{tabular}

a Soil MAAT estimates are derived using the calibration formula by Peterse et al. (2012) (Equation 7)

b Lake MAAT estimates using the calibration by Tierney et al. (2010) (Equation 8)

c Lake MAAT estimates using the calibration by Loomis et al. (2012) (Equation 9)

d b.d. = below detection limit 
Supplementary Table 3: GDGT data for sedimenting particles sampled in Lake Challa at $35 \mathrm{~m}$ depth in the period 01/12/2007-31/08/2010 and calculated MAATs using three different calibrations.

\begin{tabular}{|c|c|c|c|c|c|c|c|c|c|c|c|c|c|c|c|c|c|c|c|c|c|c|}
\hline \multirow[t]{2}{*}{ Deployment } & \multirow[t]{2}{*}{ Collection } & \multirow[t]{2}{*}{$\begin{array}{c}\text { Bulk flux } \\
\left(\mathrm{g} \mathrm{m}^{-2}\right. \\
\left.\text { day }^{-1}\right)\end{array}$} & \multirow[t]{2}{*}{$\% \mathrm{C}_{\text {org }}$} & \multirow[t]{2}{*}{$\begin{array}{l}\text { Precipitation } \\
\left(\mathrm{mm} \mathrm{month}^{-1}\right)\end{array}$} & \multicolumn{2}{|c|}{$\begin{array}{c}\sum[\mathrm{brGDGT}] \\
\left(\mu \mathrm{m} \mathrm{m}^{-2} \text { day }^{-1}\right)\end{array}$} & \multirow[t]{2}{*}{$\begin{array}{c}\% \mathrm{IPL} \\
\Sigma(\text { brGDGT) }\end{array}$} & \multicolumn{2}{|c|}{ MBT } & \multicolumn{2}{|c|}{ CBT } & \multicolumn{2}{|c|}{ BIT } & \multicolumn{2}{|c|}{$\begin{array}{l}\text { MAAT - } \\
\text { soili }\left({ }^{(} \mathrm{C}\right)\end{array}$} & \multicolumn{2}{|c|}{$\begin{array}{l}\text { MAAT - } \\
\text { lake }{ }^{\mathrm{b}}\left({ }^{\circ} \mathrm{C}\right)\end{array}$} & \multicolumn{2}{|c|}{$\begin{array}{l}\text { MAAT - } \\
\text { lake }^{\circ}\left({ }^{\circ} \mathrm{C}\right)\end{array}$} & \multicolumn{2}{|c|}{$\begin{array}{l}\text { [Crenarchaeol] } \\
\left(\mu \mathrm{g} \mathrm{m}^{-2} \text { day }^{-1}\right)\end{array}$} & \multirow[t]{2}{*}{ \%IPL Cren } \\
\hline & & & & & $\mathrm{IPL}$ & $\mathrm{CL}$ & & $\mathrm{IPL}$ & $\mathrm{CL}$ & IPL & $\mathrm{CL}$ & $\mathrm{IPL}$ & $\mathrm{CL}$ & IPL & $\mathrm{CL}$ & $\mathrm{IPL}$ & $\mathrm{CL}$ & $\mathrm{IPL}$ & $\mathrm{CL}$ & $\mathrm{IPL}$ & $\mathrm{CL}$ & \\
\hline $01 / 12 / 2007$ & $31 / 12 / 2007$ & 0.2 & 19.8 & 0 & 0.6 & 0.7 & 46 & 0.33 & 0.25 & 0.77 & 0.77 & 0.27 & 0.16 & 6.6 & 4.0 & 17.8 & 15.3 & 16.9 & 14.6 & 1.5 & 3.4 & 30 \\
\hline $31 / 12 / 2007$ & $30 / 01 / 2008$ & 0.1 & 21.2 & 6 & 1.0 & 0.8 & 54 & 0.24 & 0.20 & 0.77 & 0.94 & 0.42 & 0.19 & 4.0 & 1.7 & 15.9 & 12.1 & 14.7 & 11.1 & 1.2 & 3.2 & 27 \\
\hline $30 / 01 / 2008$ & 29/02/2008 & 0.3 & 16.8 & 4 & 1.3 & 2.2 & 37 & 0.27 & 0.23 & 0.52 & 0.56 & 0.59 & 0.45 & 6.3 & 4.7 & 18.7 & 17.3 & 18.8 & 14.8 & 0.7 & 2.2 & 25 \\
\hline 29/02/2008 & $31 / 03 / 2008$ & 4.0 & 2.7 & 451 & 0.7 & 1.3 & 35 & 0.43 & 0.41 & 0.49 & 0.40 & 0.63 & 0.59 & 11.4 & 11.5 & 21.7 & 22.2 & 22.9 & 20.6 & 0.3 & 0.6 & 33 \\
\hline $31 / 03 / 2008$ & $30 / 04 / 2008$ & 2.0 & 3.0 & 58 & 0.2 & 0.7 & 21 & 0.47 & 0.39 & 0.48 & 0.44 & 0.49 & 0.67 & 12.7 & 10.3 & 20.6 & 21.4 & 26.3 & 24.2 & 0.2 & 0.3 & 36 \\
\hline $30 / 04 / 2008$ & $31 / 05 / 2008$ & 0.2 & 11.4 & 1 & 0.2 & 0.2 & 45 & 0.45 & 0.33 & 0.50 & 0.38 & 0.47 & 0.33 & 12.5 & 8.8 & 23.3 & 22.7 & 27.8 & 21.8 & 0.1 & 0.3 & 32 \\
\hline $31 / 05 / 2008$ & $30 / 06 / 2008$ & 0.6 & 7.7 & 0 & 0.4 & 1.0 & 31 & 0.43 & 0.38 & 0.43 & 0.43 & 0.77 & 0.81 & 11.6 & 10.2 & 23.2 & 22.9 & 25.5 & 19.2 & 0.1 & 0.2 & 37 \\
\hline $30 / 06 / 2008$ & $31 / 07 / 2008$ & 2.7 & 5.0 & 0 & 0.1 & 0.7 & 12 & 0.20 & 0.39 & 0.86 & 0.25 & 0.75 & 0.80 & 2.1 & 11.6 & 19.4 & 23.0 & 12.7 & 25.7 & 0.0 & 0.1 & 19 \\
\hline $31 / 07 / 2008$ & $31 / 08 / 2008$ & 4.6 & 4.9 & 0 & 0.3 & 1.8 & 15 & 0.41 & 0.50 & 0.66 & 0.31 & 0.84 & 0.92 & 9.7 & 14.7 & 19.3 & 24.9 & 18.4 & 23.5 & 0.0 & 0.1 & 33 \\
\hline $31 / 08 / 2008$ & $30 / 09 / 2008$ & 3.4 & 5.7 & 0 & 0.3 & 1.7 & 15 & 0.27 & 0.23 & 0.96 & 0.87 & 0.98 & 0.98 & 3.9 & 3.0 & 13.1 & 13.4 & 13.3 & 12.2 & 0.0 & 0.0 & 17 \\
\hline 30/09/2008 & $31 / 10 / 2008$ & 0.5 & 10.1 & 0 & 0.4 & 2.4 & 16 & 0.20 & 0.20 & 1.58 & 1.37 & 0.98 & 0.99 & -1.9 & -0.6 & 10.5 & 10.7 & 9.3 & 9.1 & 0.0 & 0.0 & 35 \\
\hline $31 / 10 / 2008$ & $30 / 11 / 2008$ & 1.6 & 7.5 & 60 & 0.4 & 3.1 & 13 & 0.19 & 0.16 & 1.65 & 1.38 & 0.99 & 1.00 & -2.8 & -2.0 & 10.0 & 9.1 & 8.9 & 7.6 & 0.0 & 0.0 & 22 \\
\hline $30 / 11 / 2008$ & 20/12/2008 & 0.8 & 9.1 & 10 & 2.2 & 12.0 & 15 & 0.13 & 0.13 & 1.59 & 1.38 & 0.99 & 0.99 & -4.2 & -3.0 & 7.5 & 6.8 & 6.0 & 6.0 & 0.0 & 0.1 & 21 \\
\hline 20/12/2008 & $30 / 01 / 2009$ & 0.6 & 8.2 & 10 & 0.5 & 2.9 & 15 & 0.17 & 0.18 & 1.13 & 1.00 & 0.96 & 0.98 & -0.3 & 0.6 & 10.2 & 10.5 & 8.0 & 8.8 & 0.0 & 0.1 & 25 \\
\hline $30 / 01 / 2009$ & 28/02/2009 & 0.2 & 10.1 & 15.3 & 0.5 & 2.1 & 19 & 0.22 & 0.22 & 0.68 & 0.65 & 0.95 & 0.98 & 3.9 & 4.0 & 15.0 & 15.2 & 12.9 & 12.8 & 0.0 & 0.0 & 36 \\
\hline 28/02/2009 & $30 / 03 / 2009$ & 0.2 & 19.7 & 12.8 & 0.6 & 2.5 & 20 & 0.36 & 0.32 & 0.57 & 0.60 & 0.98 & 0.98 & 8.6 & 7.4 & 19.3 & 18.8 & 18.7 & 16.5 & 0.0 & 0.0 & 24 \\
\hline $30 / 03 / 2009$ & $30 / 04 / 2009$ & 0.1 & 24.9 & 18.2 & 0.1 & 0.4 & 16 & 0.28 & 0.26 & 0.49 & 0.54 & 0.97 & 0.98 & 6.8 & 5.8 & 18.4 & 18.1 & 15.8 & 14.6 & 0.0 & 0.0 & 28 \\
\hline $30 / 04 / 2009$ & $30 / 05 / 2009$ & 0.2 & 25.8 & 36 & 0.5 & 2.2 & 18 & 0.24 & 0.25 & 0.49 & 0.50 & 0.97 & 0.99 & 5.6 & 5.8 & 17.5 & 17.6 & 12.3 & 13.9 & 0.0 & 0.0 & 32 \\
\hline $30 / 05 / 2009$ & $30 / 06 / 2009$ & 0.2 & 29.9 & 0 & 0.3 & 1.7 & 17 & 0.25 & 0.25 & 0.52 & 0.53 & 0.98 & 0.99 & 5.6 & 5.8 & 17.0 & 17.7 & 16.4 & 14.1 & 0.0 & 0.0 & 28 \\
\hline $30 / 06 / 2009$ & $30 / 07 / 2009$ & 0.1 & 23.6 & 8 & 0.2 & 0.9 & 16 & 0.38 & 0.35 & 0.51 & 0.49 & 0.96 & 0.98 & 9.8 & 9.1 & 21.7 & 21.8 & 17.9 & 16.8 & 0.0 & 0.0 & 23 \\
\hline $30 / 07 / 2009$ & $31 / 08 / 2009$ & 0.3 & 25.6 & 0 & 0.1 & 0.6 & 17 & 0.34 & 0.32 & 0.45 & 0.40 & 0.94 & 0.98 & 9.1 & 8.5 & 22.3 & 22.7 & 17.6 & 18.7 & 0.0 & 0.0 & 35 \\
\hline $31 / 08 / 2009$ & $30 / 09 / 2009$ & 0.8 & 17.9 & 0 & 0.1 & 0.7 & 13 & 0.34 & 0.31 & 0.48 & 0.42 & 0.90 & 0.98 & 8.8 & 8.2 & 22.7 & 22.9 & 21.9 & 20.2 & 0.0 & 0.0 & 43 \\
\hline $30 / 09 / 2009$ & $30 / 10 / 2009$ & 1.4 & 12.0 & 0 & 0.1 & 0.8 & 14 & 0.26 & 0.27 & 0.65 & 0.48 & 0.95 & 0.98 & 5.3 & 6.5 & 17.1 & 19.5 & 12.4 & 15.4 & 0.0 & 0.0 & 31 \\
\hline $30 / 10 / 2009$ & $30 / 11 / 2009$ & 1.2 & 8.3 & 17.8 & 0.2 & 0.7 & 18 & 0.25 & 0.24 & 0.86 & 0.72 & 0.98 & 0.98 & 3.8 & 4.2 & 14.6 & 15.0 & 11.3 & 11.9 & 0.0 & 0.0 & 19 \\
\hline $30 / 11 / 2009$ & 27/12/2009 & 1.1 & 6.1 & 330 & 0.2 & 1.4 & 14 & 0.27 & 0.22 & 0.88 & 0.93 & 0.92 & 0.87 & 4.3 & 2.3 & 13.5 & 12.2 & 13.3 & 9.8 & 0.0 & 0.2 & 8 \\
\hline 27/12/2009 & $30 / 01 / 2010$ & 5.1 & 5.1 & 260 & 0.2 & 1.3 & 15 & 0.24 & 0.18 & 0.88 & 1.08 & 0.60 & 0.50 & 3.4 & 0.3 & 12.8 & 9.7 & 11.8 & 7.7 & 0.1 & 1.2 & 10 \\
\hline $30 / 01 / 2010$ & 28/02/2010 & 0.1 & 20.7 & 37.5 & 0.1 & 0.7 & 9 & 0.20 & 0.15 & 1.08 & 1.03 & 0.57 & 0.37 & 0.8 & -0.4 & 10.2 & 9.1 & 10.3 & 7.2 & 0.1 & 1.2 & 4 \\
\hline 28/02/2010 & $31 / 03 / 2010$ & 0.2 & 14.6 & 3.4 & 0.2 & 1.0 & 13 & 0.26 & 0.19 & 0.87 & 0.90 & 0.22 & 0.19 & 3.8 & 1.7 & 13.4 & 11.3 & 9.0 & 9.3 & 0.5 & 4.3 & 11 \\
\hline $31 / 03 / 2010$ & $30 / 04 / 2010$ & 0.4 & 17.5 & 140 & 0.1 & 0.5 & 14 & 0.31 & 0.22 & 0.69 & 0.79 & 0.11 & 0.09 & 6.4 & 3.2 & 15.9 & 16.1 & 16.8 & 12.6 & 0.5 & 4.4 & 11 \\
\hline $30 / 04 / 2010$ & $31 / 05 / 2010$ & 0.1 & 21.4 & 10.1 & 0.0 & 0.4 & 7 & 0.45 & 0.30 & 0.61 & 0.56 & 0.12 & 0.09 & 11.1 & 6.9 & 19.5 & 18.9 & 22.4 & 15.1 & 0.2 & 2.9 & 6 \\
\hline $31 / 05 / 2010$ & $28 / 06 / 2010$ & 0.2 & 26.6 & 0 & 0.0 & 0.4 & 8 & 0.43 & 0.33 & 0.66 & 0.55 & 0.41 & 0.26 & 10.4 & 8.0 & 20.2 & 20.7 & 22.1 & 16.0 & 0.0 & 0.9 & 5 \\
\hline 28/06/2010 & $30 / 07 / 2010$ & 0.2 & 26.3 & 0 & 0.1 & 0.4 & 18 & 0.68 & 0.37 & 0.19 & 0.48 & 0.40 & 0.56 & 20.9 & 9.8 & 24.6 & 22.7 & 27.7 & 19.3 & 0 & 0. & 26 \\
\hline $30 / 07 / 2010$ & $31 / 08 / 2010$ & 0.2 & 16.1 & 0 & 0.0 & 0.4 & 7 & 0.35 & 0.31 & 0.48 & 0.45 & 0.78 & 0.72 & 9.0 & 8.0 & 21.4 & 22.0 & 21.5 & 18.4 & 0.0 & 0.1 & 6 \\
\hline
\end{tabular}

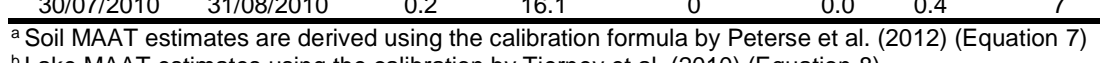

${ }^{b}$ Lake MAAT estimates using the calibration by Tierney et al. (2010) (Equation 8) 
Supplementary Table 4: GDGT data for surface sediments sampled in Lake Challa at different locations and calculated MAATs using three different calibrations.

\begin{tabular}{|c|c|c|c|c|c|c|c|c|c|c|c|c|c|c|c|c|c|c|c|c|c|c|c|}
\hline \multirow[t]{2}{*}{ Core } & \multirow[t]{2}{*}{$\begin{array}{l}\text { Depth } \\
\text { interval } \\
(\mathrm{cm})\end{array}$} & \multicolumn{2}{|c|}{ UTM coordinates } & \multirow[t]{2}{*}{$\begin{array}{c}\text { Water } \\
\text { depth (m) }\end{array}$} & \multirow[t]{2}{*}{$\%$ org } & \multicolumn{2}{|c|}{$\underset{\left.\mathrm{g}^{-1} \mathrm{Corg}^{2}\right)}{[\mathrm{brGGT]}}(\mu \mathrm{g}$} & \multirow[t]{2}{*}{$\begin{array}{c}\% \mathrm{IPL} \\
\Sigma(\mathrm{brGDGT})\end{array}$} & \multicolumn{2}{|c|}{ MBT } & \multicolumn{2}{|c|}{ CBT } & \multicolumn{2}{|c|}{ BIT } & \multicolumn{2}{|c|}{$\begin{array}{l}\text { MAAT - } \\
\text { soila }\left({ }^{\circ} \mathrm{C}\right)\end{array}$} & \multicolumn{2}{|c|}{$\begin{array}{l}\text { MAAT - lakeb } \\
\left({ }^{\circ} \mathrm{C}\right)\end{array}$} & \multicolumn{2}{|c|}{$\begin{array}{c}\text { MAAT - lake }{ }^{\mathrm{c}} \\
\left({ }^{\circ} \mathrm{C}\right)\end{array}$} & \multicolumn{2}{|c|}{$\begin{array}{l}\text { [Crenarchaeol] } \\
\left(\mu \mathrm{g} \mathrm{g}^{-1} \text { Corg }\right)\end{array}$} & \multirow[t]{2}{*}{$\begin{array}{l}\% \text { IPL } \\
\text { Cren. }\end{array}$} \\
\hline & & Easting & Northing & & & $\mathrm{IPL}$ & $\mathrm{CL}$ & & $\mathrm{IPL}$ & $\mathrm{CL}$ & $\mathrm{IPL}$ & $\mathrm{CL}$ & $\mathrm{IPL}$ & $\mathrm{CL}$ & $\mathrm{IPL}$ & $\mathrm{CL}$ & $\mathrm{IPL}$ & $\mathrm{CL}$ & $\mathrm{IPL}$ & $\mathrm{CL}$ & $\mathrm{IPL}$ & $\mathrm{CL}$ & \\
\hline $\mathrm{CH} 10-01 \mathrm{G}$ & $0-1$ & 355848 & 9633974 & 75.0 & 8.0 & 15.3 & 82.0 & 16 & 0.33 & 0.34 & 0.73 & 0.64 & 0.95 & 0.97 & 7.0 & 7.7 & 19.1 & 19.5 & 16.3 & 17.1 & 0.6 & 1.9 & 25 \\
\hline $\mathrm{CH} 10-02 \mathrm{G}$ & $0-1$ & 355663 & 9633310 & 90.7 & 13.6 & 11.4 & 45.1 & 20 & 0.41 & 0.45 & 0.70 & 0.63 & 0.88 & 0.72 & 9.7 & 11.2 & 20.2 & 21.2 & 19.7 & 21.8 & 1.4 & 14.1 & 9 \\
\hline $\mathrm{CH} 10-03 \mathrm{G}$ & $0-1$ & n.d. ${ }^{d}$ & n.d. & 89.0 & 14.9 & 23.2 & 64.3 & 27 & 0.37 & 0.40 & 0.72 & 0.67 & 0.81 & 0.76 & 8.2 & 9.5 & 19.7 & 20.1 & 18.4 & 20.1 & 4.5 & 17.2 & 21 \\
\hline $\mathrm{CH} 10-04 \mathrm{G}$ & $0-1$ & 356839 & 9633523 & 43.9 & 9.4 & 12.0 & 72.1 & 14 & 0.27 & 0.30 & 0.67 & 0.54 & 0.93 & 0.94 & 5.5 & 7.1 & 19.0 & 20.0 & 14.0 & 16.1 & 0.8 & 3.4 & 18 \\
\hline $\mathrm{CH} 10-05 \mathrm{G}$ & $0-1$ & 356752 & 9633461 & 54.9 & 8.2 & 19.8 & 106.0 & 16 & 0.32 & 0.31 & 0.77 & 0.64 & 0.94 & 0.97 & 6.4 & 6.8 & 18.5 & 18.7 & 15.7 & 15.7 & 1.0 & 2.8 & 27 \\
\hline $\mathrm{CH} 10-06 \mathrm{G}$ & $0-1$ & 355347 & 9633219 & 91.6 & 9.4 & 18.4 & 105.7 & 15 & 0.32 & 0.30 & 0.79 & 0.73 & 0.99 & 0.98 & 6.4 & 6.0 & 18.3 & 17.7 & 16.2 & 15.7 & 0.2 & 1.7 & 12 \\
\hline $\mathrm{CH} 10-07 \mathrm{G}$ & $0-1$ & 355002 & 9633316 & 91.3 & 9.4 & 29.3 & 80.6 & 27 & 0.41 & 0.43 & 0.76 & 0.71 & 0.81 & 0.77 & 9.2 & 10.3 & 19.7 & 19.8 & 18.8 & 20.0 & 5.7 & 20.1 & 22 \\
\hline $\mathrm{CH} 10-08 \mathrm{G}$ & $0-1$ & 354708 & 9633489 & 88.5 & 8.0 & 18.7 & 99.8 & 16 & 0.32 & 0.32 & 0.80 & 0.74 & 0.97 & 0.98 & 6.1 & 6.7 & 18.1 & 18.0 & 16.2 & 15.9 & 0.5 & 1.9 & 21 \\
\hline $\mathrm{CH} 10-09 \mathrm{G}$ & $0-1$ & 354548 & 9633854 & 75 & 7.2 & 15.9 & 82.0 & 16 & 0.34 & 0.31 & 0.80 & 0.71 & 0.96 & 0.97 & 6.9 & 6.3 & 18.4 & 17.7 & 16.2 & 15.7 & 0.6 & 2.2 & 21 \\
\hline $\mathrm{CH} 10-10 \mathrm{G}$ & $0-1$ & 354494 & 9634091 & 64.7 & 5.6 & 8.5 & 65.7 & 11 & 0.35 & 0.32 & 0.84 & 0.72 & 0.96 & 0.97 & 6.9 & 6.7 & 17.6 & 17.9 & 14.6 & 15.3 & 0.3 & 1.7 & 14 \\
\hline $\mathrm{CH} 10-11 \mathrm{G}$ & $0-1$ & 354360 & 9634187 & 32.8 & 2.5 & 9.4 & 53.9 & 15 & 0.42 & 0.45 & 0.38 & 0.35 & 0.92 & 0.91 & 11.9 & 12.8 & 26.3 & 26.9 & 18.2 & 19.8 & 0.6 & 3.5 & 14 \\
\hline $\mathrm{CH} 10-12 \mathrm{G}$ & $0-1$ & 356063 & 9633966 & 72.7 & 9.1 & 13.6 & 58.7 & 19 & 0.36 & 0.39 & 0.58 & 0.47 & 0.77 & 0.73 & 8.9 & 10.2 & 21.1 & 22.5 & 16.7 & 18.5 & 3.1 & 15.9 & 16 \\
\hline $\mathrm{CH} 10-14 \mathrm{G}$ & $0-1$ & 356579 & 9633029 & 62 & 8.9 & 12.4 & 72.3 & 15 & 0.31 & 0.31 & 0.74 & 0.64 & 0.97 & 0.97 & 6.3 & 6.9 & 18.5 & 18.5 & 15.7 & 15.7 & 0.3 & 2.0 & 15 \\
\hline $\mathrm{CH} 10-16 \mathrm{~Gb}$ & $0.5-1$ & 356284 & 9633372 & 68.2 & 10.1 & 16.1 & 96.6 & 14 & 0.31 & 0.32 & 0.69 & 0.64 & 0.98 & 0.99 & 6.6 & 7.3 & 19.1 & 18.9 & 15.8 & 16.5 & 0.3 & 1.1 & 20 \\
\hline $\mathrm{CH} 10-17 \mathrm{G}$ & $0-1$ & 356362 & 9633296 & 89.1 & 10.6 & 22.3 & 116.5 & 16 & 0.31 & 0.31 & 0.78 & 0.69 & 0.97 & 0.98 & 6.2 & 6.4 & 18.3 & 17.9 & 16.0 & 15.9 & 0.5 & 2.4 & 17 \\
\hline $\mathrm{CH} 10-18 \mathrm{G}$ & $0-1$ & 355941 & 9633423 & 86.1 & 9.7 & 16.2 & 92.4 & 15 & 0.30 & 0.31 & 0.81 & 0.72 & 0.97 & 0.98 & 5.4 & 6.3 & 17.8 & 18.1 & 15.4 & 15.8 & 0.4 & 1.8 & 19 \\
\hline $\mathrm{CH} 10-19 \mathrm{G}$ & $0-1$ & 355005 & 9633814 & 90.4 & 12.2 & 36.5 & 94.3 & 28 & 0.37 & 0.38 & 0.72 & 0.67 & 0.72 & 0.68 & 8.3 & 8.9 & 19.9 & 19.7 & 18.1 & 18.9 & 11.7 & 36.4 & 24 \\
\hline $\mathrm{CH} 10-20 \mathrm{G}$ & $0-1$ & 354738 & 9633990 & 89.2 & 9.2 & 15.8 & 73.6 & 18 & 0.31 & 0.31 & 0.80 & 0.75 & 0.99 & 0.98 & 6.0 & 6.1 & 18.1 & 17.5 & 16.0 & 15.3 & 0.2 & 1.3 & 12 \\
\hline $\mathrm{CH} 10-21 \mathrm{Ga}$ & $0-0.5$ & 354447 & 9634123 & 78.7 & 8.6 & 16.5 & 75.7 & 18 & 0.27 & 0.26 & 0.78 & 0.67 & 0.93 & 0.94 & 4.8 & 5.1 & 17.5 & 17.4 & 14.9 & 14.2 & 1.1 & 3.9 & 21 \\
\hline $\mathrm{CH} 10-21 \mathrm{~Gb}$ & $0.5-1$ & 354447 & 9634123 & 78.7 & 8.2 & 20.9 & 101.6 & 17 & 0.37 & 0.33 & 0.80 & 0.71 & 0.98 & 0.99 & 7.6 & 7.2 & 18.5 & 18.3 & 16.9 & 16.3 & 0.4 & 1.1 & 27 \\
\hline $\mathrm{CH} 10-22 \mathrm{G}$ & $0-1$ & 354763 & 9632314 & 59.7 & 3.5 & 50.1 & 209.4 & 19 & 0.33 & 0.33 & 0.71 & 0.64 & 0.85 & 0.70 & 7.0 & 7.5 & 19.4 & 19.3 & 16.6 & 17.1 & 7.5 & 72.4 & 9 \\
\hline $\mathrm{CH} 10-23 \mathrm{G}$ & $0-1$ & 355918 & 9632732 & 82 & 9.4 & 16.6 & 90.9 & 15 & 0.32 & 0.31 & 0.75 & 0.67 & 0.96 & 0.97 & 6.4 & 6.7 & 18.6 & 18.6 & 15.9 & 16.0 & 0.6 & 2.3 & 21 \\
\hline $\mathrm{CH} 10-24 \mathrm{G}$ & $0-1$ & 355960 & 9632804 & 89 & 10.8 & 25.8 & 95.3 & 21 & 0.29 & 0.30 & 0.81 & 0.71 & 0.97 & 0.97 & 5.1 & 6.0 & 18.0 & 18.0 & 15.2 & 15.5 & 0.8 & 2.2 & 26 \\
\hline $\mathrm{CH} 10-25 \mathrm{G}$ & $0-1$ & 356488 & 9633121 & 73.4 & 8.4 & 13.1 & 81.0 & 14 & 0.31 & 0.31 & 0.75 & 0.68 & 0.93 & 0.96 & 6.2 & 6.8 & 18.4 & 18.1 & 15.5 & 15.8 & 0.8 & 2.7 & 23 \\
\hline
\end{tabular}

a Soil MAAT estimates are derived using the calibration formula by Peterse et al. (2012) (Equation 7)

cake MAAT estimates using the calibration by Tierney et al. (2010) (Equation 8)

${ }^{d}$ n.d. $=$ not determined 
Supplementary Table 5: GDGT data for different $(0-13 \mathrm{~cm})$ sediment horizons from Lake Challa and calculated MAATs using three different calibrations.

\begin{tabular}{|c|c|c|c|c|c|c|c|c|c|c|c|c|c|c|}
\hline \multirow[t]{2}{*}{$\begin{array}{l}\text { Core } \\
\text { code }\end{array}$} & \multirow[t]{2}{*}{$\begin{array}{c}\text { Depth } \\
\text { interval } \\
(\mathrm{cm})\end{array}$} & \multirow[t]{2}{*}{$\begin{array}{c}\% \text { IPL } \\
\Sigma(\text { brGDGT })\end{array}$} & \multicolumn{2}{|c|}{ BIT } & \multicolumn{2}{|c|}{ MBT } & \multicolumn{2}{|c|}{ CBT } & \multicolumn{2}{|c|}{$\begin{array}{l}\text { MAAT - } \\
\text { soilla }\left({ }^{\circ} \mathrm{C}\right)\end{array}$} & \multicolumn{2}{|c|}{$\begin{array}{l}\text { MAAT - } \\
\text { lake }\left({ }^{\circ} \mathrm{C}\right)\end{array}$} & \multicolumn{2}{|c|}{$\begin{array}{l}\text { MAAT - } \\
\text { lake }^{\circ}\left({ }^{\circ} \mathrm{C}\right)\end{array}$} \\
\hline & & & $\mathrm{IPL}$ & $\mathrm{CL}$ & $\mathrm{IPL}$ & $\mathrm{CL}$ & $\mathrm{IPL}$ & $\mathrm{CL}$ & $\mathrm{IPL}$ & $\mathrm{CL}$ & $\mathrm{IPL}$ & $\mathrm{CL}$ & $\mathrm{IPL}$ & $\mathrm{CL}$ \\
\hline CH08-1G & $0.0-0.5$ & 48 & 0.86 & 0.61 & 0.45 & 0.41 & 0.67 & 0.70 & 10.9 & 9.7 & 21.1 & 19.9 & 21.9 & 19.6 \\
\hline $\mathrm{CH} 08-1 \mathrm{G}$ & $0.5-1.0$ & 28 & 0.92 & 0.88 & 0.51 & 0.54 & 0.69 & 0.67 & 12.6 & 13.9 & 21.5 & 21.5 & 20.8 & 23.4 \\
\hline $\mathrm{CH} 08$ 1G & $1.0-1.5$ & 27 & 0.94 & 0.90 & 0.51 & 0.54 & 0.72 & 0.70 & 12.4 & 13.6 & 21.3 & 21.4 & 21.8 & 23.0 \\
\hline $\mathrm{CH} 08-1 \mathrm{G}$ & $1.5-2.0$ & 41 & 0.86 & 0.69 & 0.45 & 0.41 & 0.65 & 0.68 & 11.1 & 9.7 & 20.9 & 20.0 & 21.5 & 20.0 \\
\hline $\mathrm{CH} 08-1 \mathrm{G}$ & $2.0-2.5$ & 20 & 0.74 & 0.68 & 0.36 & 0.41 & 0.72 & 0.69 & 7.8 & 9.5 & 19.2 & 19.7 & 17.8 & 19.6 \\
\hline $\mathrm{CH} 08-1 \mathrm{G}$ & $2.5-3.0$ & 37 & 0.85 & 0.70 & 0.43 & 0.42 & 0.68 & 0.70 & 10.3 & 10.0 & 20.7 & 20.1 & 20.7 & 20.4 \\
\hline $\mathrm{CH} 08-1 \mathrm{G}$ & $3.0-3.5$ & 19 & 0.78 & 0.67 & 0.38 & 0.43 & 0.65 & 0.63 & 9.0 & 10.7 & 20.3 & 21.1 & 18.8 & 21.3 \\
\hline $\mathrm{CH} 08-1 \mathrm{G}$ & $3.5-4.0$ & 26 & 0.85 & 0.79 & 0.42 & 0.42 & 0.78 & 0.64 & 9.4 & 10.1 & 19.2 & 20.3 & 19.6 & 21.3 \\
\hline $\mathrm{CH} 08-1 \mathrm{G}$ & $4.0-4.5$ & 33 & 0.72 & 0.52 & 0.44 & 0.42 & 0.66 & 0.62 & 10.6 & 10.3 & 20.5 & 20.9 & 22.5 & 21.2 \\
\hline $\mathrm{CH} 08-1 \mathrm{G}$ & $4.5-5.0$ & 34 & 0.82 & 0.68 & 0.44 & 0.42 & 0.61 & 0.63 & 11.2 & 10.4 & 21.2 & 20.5 & 22.0 & 21.5 \\
\hline $\mathrm{CH} 08-1 \mathrm{G}$ & $7.0-7.5$ & 19 & 0.72 & 0.58 & 0.39 & 0.46 & 0.68 & 0.62 & 9.0 & 11.4 & 20.5 & 21.1 & 17.2 & 21.7 \\
\hline $\mathrm{CH} 08-1 \mathrm{G}$ & $9.0-9.5$ & 27 & 0.74 & 0.57 & 0.41 & 0.46 & 0.61 & 0.54 & 10.0 & 12.0 & 21.3 & 22.2 & 17.8 & 22.3 \\
\hline $\mathrm{CH} 08-1 \mathrm{G}$ & $11.0-11.5$ & 25 & 0.78 & 0.60 & 0.41 & 0.45 & 0.65 & 0.62 & 9.8 & 11.4 & 21.1 & 21.1 & 19.1 & 20.6 \\
\hline $\mathrm{CH} 08-1 \mathrm{G}$ & $13.0-13.5$ & 33 & 0.90 & 0.75 & 0.40 & 0.38 & 0.74 & 0.60 & 8.9 & 9.3 & 19.8 & 20.8 & 16.4 & 20.5 \\
\hline
\end{tabular}

a Soil MAAT estimates are derived using the calibration formula by Peterse et al. (2012) (Equation 7)

b Lake MAAT estimates using the calibration by Tierney et al. (2010) (Equation 8)

c Lake MAAT estimates using the calibration by Loomis et al. (2012) (Equation 9) 